Article

\title{
Explaining the Diffusion of Renewable Electricity Technologies in Canadian Remote Indigenous Communities through the Technological Innovation System Approach
}

\author{
Konstantinos Karanasios * and Paul Parker(D) \\ Department of Geography and Environmental Management, University of Waterloo, \\ Waterloo, ON N2L 3G1, Canada; pparker@uwaterloo.ca \\ * Correspondence: kkaranasios@uwaterloo.ca
}

Received: 19 September 2018; Accepted: 22 October 2018; Published: 24 October 2018

check for updates

\begin{abstract}
This paper applies the Technological Innovation System (TIS) approach for the first time in the context of remote indigenous communities in Northwest Territories (NWT) and Ontario, Canada, to explain the diffusion of Renewable Energy Technologies (RETs). These communities need reliable and sustainable electricity to address social, environmental and economic development issues. The study examines the diffusion of RETs during the 2000-2016 period, identifies the systemic and transformational failures responsible for the functional performance of the TISs, and generates insights about factors that have the potential to sustain the development of RET projects. Findings suggest that the TIS-proposed causal mechanisms were present and performed as expected. Since the accumulation of TIS functions influences the rate of deployment of renewable technologies, policy intervention to improve local learning and networking could lead to accelerated diffusion of RETs to the benefit of remote communities and other stakeholders.
\end{abstract}

Keywords: technological innovation system; sustainable electricity systems; renewable energy; remote indigenous communities

\section{Introduction}

There is increasing interest in the role of renewable energy technologies (RETs) within community sustainability transitions, ranging from energy efficiency measures to energy efficient housing development and local electricity generation [1-3]. Overall, 144 Canadian remote indigenous communities, with an approximate population of 100,000, depend upon diesel generators to meet their electricity needs $[4,5]$. Remote, or off-grid, communities are permanent or long term (five years or more) settlements with at least 10 dwellings that are not connected to the North American electricity grid or the piped natural gas network [5]. The transformation of these local electrical systems through the introduction of RETs therefore has the potential to reduce environmental impacts in the form of carbon emissions, fuel spills and leakages, increase electricity supply and reliability, as well as improve socioeconomic conditions through new housing and business connections and reductions of community electrification costs [4].

However, despite the multiple potential benefits of RETs in off-grid communities [6], the diffusion of such projects remains low. Research in 133 remote indigenous communities indicates 71 RET projects in Yukon, Northwest Territories (NWT), Ontario, British Columbia, Ontario, Quebec and Newfoundland and Labrador between 1980 and 2016 with a total of $31.5 \mathrm{MW}$ or $13 \%$ of the total electricity generation capacity. However, if hydroelectricity is excluded, 63 of these projects were small scale wind and solar applications with a total capacity of $1.6 \mathrm{MW}$, or less than $1 \%$ of the total electricity 
generation capacity. Fifty-three of these projects were developed after 2006 and the majority were installed in NWT (29 projects) and Ontario (13 projects) [7-13].

Prior research on the introduction of RETs in remote indigenous communities' electrical systems concentrates on the identification of technical factors that influence a project's financial viability, such as the choice over the extent of the renewable energy resource component (low, medium or high penetration RET integration), economies of scale, developers' expertise, availability of distribution infrastructure, smart grid considerations, lower cost storage technology, reliable, robust equipment, and packaged systems using plug-and-play control technologies (see for example, References [14-21]).

In addition to quantitative studies, a limited number of qualitative contributions provide insights on structural, institutional and sociocultural factors for the successful deployment of RET projects in Canadian remote indigenous communities [22-25]. Furthermore, the dynamics of the transition of remote indigenous communities' electrical systems to more sustainable ones have been explained using the Multi-Level Perspective (MLP) framework [26,27] and the interaction of co-evolving factors, such as destabilizing mechanisms at the landscape level, stabilizing mechanisms and governance structures at the regime level, and the adoption of innovative technologies at the niche level [28]. However, the MLP is unable to elaborate in detail, first, how the implemented governance structures that influenced the transition process came about, and, second, the roles and strategies of participating actors, the interactions between actors and institutions, and the role of resource distribution in the development of networks and actors' capacity $[29,30]$.

This level of detail could be provided through the technological innovation system (TIS) approach and the use of functions and functional interactions [31]. The TIS approach defines innovation systems as "a dynamic network of agents interacting in a specific economic/industrial area under a particular institutional infrastructure and involved in the generation, diffusion and utilization of technology (Carlsson and Stankiewicz, 1991, p. 111)" (cited in Reference [29]). Actors, institutions and interactions (relationships) between them are introduced as the unit of analysis [31,32]. Actors include private consumers, firms, governmental agencies, universities, non-governmental organizations (NGOs) and a multitude of other organizations participating in any given technological innovation. Institutions are considered the laws and regulations, technical, formal and informal rules and norms, visions, and expectations that shape the interactions among actors [29]. Finally, interactions (or relationships) are means of transferring codified and tacit knowledge at the individual or organizational level; as such, interactions are developed and exchanged between the elements of the system through cooperative relationships or the establishment of networks between different actors, between actors and institutions, and among institutions [29]. Wieczorek and Hekkert add infrastructure, in the form of physical (artifacts, machines, roads, buildings), financial (financial programs, subsidies, grants), and knowledge (expertise, know how, strategic information), as important structural components, the existence and performance of which may directly influence the uptake of a certain TIS [33].

The performance of a TIS depends on the way that actors engage and interact with each other at multiple levels thereby influencing the quality of three main functions, the generation, diffusion, and use of the innovation investigated $[34,35]$. These functions, in turn, depend on the quality and interactions generated by a set of "sub-functions", defined as F1 (entrepreneurial activities), F2 (knowledge development), F3 (knowledge diffusion), F4 (guidance of the search), F5 (market formation), F6 (mobilization of resources), and F7 (creation of legitimacy/support from advocacy coalitions) [31,32]. It is during the formative period of the TIS that the interactions between sub-functions may create virtuous cycles (or motors of innovation) or processes of cumulative causation leading to the uptake of the TIS; the successful fulfillment of a function possibly leads to the fulfillment of other functions leading to the reinforcement of the process and a virtuous cycle $[31,36]$. The sub-functions in turn are influenced by the existence and quality of the structural elements, so it is the constant interplay between the system elements, coordination mechanisms, and the development of interrelations that defines the dynamic character of the TIS that may or may not lead to the uptake of certain innovative products within a specific environment [31-33]. 
Empirically, operationalization of the functional pattern is achieved through a set of indicators or diagnostic questions, which can be both qualitative and quantitative, describing the content of the function [32]; for example, entrepreneurial activities (F1) can be measured through the number of new firms established or new projects undertaken, and the function guidance of the search (F4) can be measured through the targets developed by governments or press releases that set expectations and future policy goals [29]. Mapping of TIS functions through activities (their operationalization) over a time period can additionally create an evolutionary pattern of the innovation under examination [34].

Accordingly, the uptake of a TIS can be examined through an analysis of both the functional and structural components that form the TIS. A combined functional-structural analysis will explain the diffusion of the innovation through the presence, or lack of, or weakness of functions, which, in turn, may be the result of systemic problems of the TIS examined. The systemic problems (or systemic failures or weaknesses) were categorized as actors' problems (presence and capabilities), institutional (presence and capacity), interaction (presence and quality), and infrastructure (presence and quality) problems $[33,37,38]$. Therefore, policy-related issues result from the proposition that both the structure and functions of a TIS are influenced by the existence and quality of different actors and their capabilities, institutions, and infrastructure, as well as the existence and quality of the interactions [30,32,39]. Both structure and function can be influenced by "inducement" and "blocking" mechanisms, which are responsible for the shaping of the TIS dynamics. Targeted policies may affect the mechanisms that induce the transformation process creating the "virtuous cycles" of successful activities, resulting in the moving of key processes and the diffusion of the specific technological innovation, and the transition from one sociotechnical regime to the (more sustainable) desired next one $[29,32,40]$.

The TIS approach has been criticized for its (internal) focus on innovations' functional performance and a lack of integrating external factors [29,41], concepts of power [42] and political intervention [43]. Accordingly, systemic problems within a TIS were extended to include directionality (lack of shared vision), policy coordination (lack of horizontal and vertical policy coordination), demand articulation (absence of public demand) and reflexivity (involving actors in processes of self-governance) failures [41]. Furthermore, recent TIS studies on the diffusion of RET innovations argue for exploring the link between deployment and local contexts, institutional conditions, and learning [44-47], which could only be partially captured through a comparative structural analysis of regional or national TISs [48].

In terms of empirical studies, the TIS approach has been used to examine the development, generation and deployment of innovations as either a single process in developed countries [49-51], or as an innovation aimed at replacing existing products in developing countries [39]. Furthermore, the approach has been used to examine both the deployment of infrastructural level energy innovations, such as combined heat and power [52] and district heating [53], as well as the deployment of less technologically demanding RET applications in both developed [54] and developing country contexts characterized by remoteness [55] and energy access challenges [56,57]. Accordingly, the purpose of this study is to apply the TIS approach to explain the diffusion of RET projects, primarily in the form of solar applications, in the specific political, cultural and institutional context of Canadian indigenous remote communities (see for example, References [58-60]) in Northwest Territories (NWT) and Ontario between 2000 and 2016, and generate insights about factors that have the potential to sustain their development.

This paper is structured as follows: Section 2 presents the methodological approach, followed by the results and discussion in Sections 3 and 4 . Section 5 offers concluding remarks.

\section{Materials and Methods}

To explain the diffusion of RETs in Canadian remote indigenous communities and identify factors influencing their deployment, the performance of the NWT and Ontario TIS are assessed through a combined functional and structural analysis. The steps proposed by References [32,33] are followed (Table 1). 
Table 1. Research process.

\begin{tabular}{|c|c|c|c|c|}
\hline Step & Description & $\begin{array}{l}\text { Supporting } \\
\text { Framework }\end{array}$ & Methods & Results \\
\hline Step 1 & $\begin{array}{l}\text { Definition and structure of the TISs } \\
\text { under consideration. } \\
\text { Identification of blocking mechanisms } \\
\text { that influence the functional performance } \\
\text { of the TISs. }\end{array}$ & $\begin{array}{l}\text { Table } 2 \\
\text { (based on } \\
\text { Reference [33]) }\end{array}$ & $\begin{array}{l}\text { Systematic review of academic and policy } \\
\text { documents and key informant interviews } \\
\text { in a remote indigenous community. }\end{array}$ & Section 3.1 \\
\hline Step 3 & $\begin{array}{l}\text { - Analysis and comparison of the NWT and } \\
\text { Ontario TISs functional performance } \\
\text { through event mapping. }\end{array}$ & $\begin{array}{l}\text { Table } 3 \\
\text { (based on } \\
\text { Reference [32]) }\end{array}$ & $\begin{array}{l}\text { Multiple literature reviews of academic and } \\
\text { non-academic, policy, utilities and } \\
\text { communities' literature. }\end{array}$ & Section 3.4. \\
\hline
\end{tabular}

First, the TIS under investigation is defined and the structure, functional pattern, and the main blocking mechanisms and underlying systemic problems that hinder the fulfilment of the functions in both TISs are identified using the framework presented in Table 2 (Sections 3.1 and 3.2). In a second step, the systemic problems responsible for the poor functional performance of both the NWT and Ontario TIS are "precisely identified" and analyzed [33] (p. 85) (Section 3.3).

Table 2. Framework for the analysis of the TIS in remote indigenous communities.

\begin{tabular}{|c|c|c|c|}
\hline Functions & $\begin{array}{l}\text { Evaluation of } \\
\text { Functions Based } \\
\text { on Diagnostic } \\
\text { Questions }\end{array}$ & $\begin{array}{l}\text { Identification of the } \\
\text { Reasons Affecting } \\
\text { Function Performance }\end{array}$ & $\begin{array}{l}\text { Identification of Systemic (Actors, } \\
\text { Institutions, Networks, Infrastructure), } \\
\text { and Transformational (Directionality, } \\
\text { Demand Articulation, Policy Coordination } \\
\text { and Reflexivity) Failures Responsible for the } \\
\text { Blocking/Inducement Mechanisms }\end{array}$ \\
\hline $\begin{array}{l}\text { Fn } \\
n=1,2, \ldots, 7\end{array}$ & $\ldots \ldots \ldots$ & $\begin{array}{l}\text { Blocking/inducement } \\
\text { mechanisms) affecting Fn }\end{array}$ & $\begin{array}{l}\text { Actors: Presence? Capabilities? Institutions: } \\
\text { Presence? Capacity/quality? Interactions: } \\
\text { Presence? Intensity / quality? Infrastructure: } \\
\text { Presence? Capacity/quality? Presence and } \\
\text { quality (effectiveness) of directionality } \\
\text { measures? Presence and quality (effectiveness) } \\
\text { of demand articulation measures? Presence } \\
\text { and quality (effectiveness) of policy } \\
\text { coordination measures? Presence and quality } \\
\text { (effectiveness) of reflexivity measures? }\end{array}$ \\
\hline
\end{tabular}

Adapted from [32,50]. See also [61].

In a third step, the functional performances of the NWT and Ontario TIS during the 2000-2016 period are analyzed and compared in order to, first, explain the diffusion of the TISs, and, second, to generate insights concerning the main factors that influence the deployment. Functional performance during the period investigated is assessed through mapping actors' activities (events) that changed institutions, influenced interactions and modified infrastructure, and, therefore, addressed systemic problems and contributed to TIS function changes and fulfillment. Events are then allocated to functions based on operationalization indicators [43] described in Table 3. Findings follow in the form of a narrative that explains the historic development of both TISs through changes in the structure and functions' interactions. Events that contribute positively to function fulfillment are marked with a positive $(+)$ sign, and events that influence functions in a negative way are marked with a negative $(-)$ sign (Section 3.4). 
Table 3. Functions and operationalization indicators for the NWT and Ontario TIS.

\begin{tabular}{|c|c|}
\hline System Function & Operationalization Indicators \\
\hline F1. Entrepreneurial activities & Development of remote community owned RET projects. \\
\hline F2. Knowledge development & $\begin{array}{l}\text { Conducting renewable resource surveys, monitoring studies, feasibility } \\
\text { studies. Community energy plans. Small scale RET experiments. } \\
\text { Participation in research projects. }\end{array}$ \\
\hline F3. Knowledge diffusion & $\begin{array}{l}\text { Training of community members. Promoting energy related education, } \\
\text { developing energy campaigns, organizing and participating in } \\
\text { conferences, exhibitions, workshops, charrettes, seminars, meetings. }\end{array}$ \\
\hline F4. Guidance of the search & $\begin{array}{l}\text { Establishing targets for RETs. Design of policies and regulations that } \\
\text { favor RET solutions. Design of policies and regulations that favor RET } \\
\text { solutions in remote indigenous communities. Establishing expectations } \\
\text { from RETs projects on indigenous lands. Providing direction and } \\
\text { expressing interest in RETs options. Publication of results from studies } \\
\text { involving RETs in remote communities. }\end{array}$ \\
\hline F5. Market formation & $\begin{array}{l}\text { Regulatory arrangements that allow local governments and their } \\
\text { organizations to participate in the electricity generation process as } \\
\text { Independent Power Producers (IPP). Power Purchase Agreements } \\
\text { (PPAs). Net metering agreements. }\end{array}$ \\
\hline F6. Resource mobilization & $\begin{array}{l}\text { Providing financial incentives (for project capital, technical training, } \\
\text { electricity generation). Providing loans. Providing loan guarantees. } \\
\text { Financing research projects. Mobilizing cooperation with the private sector. }\end{array}$ \\
\hline $\begin{array}{l}\text { F7. Support from advocacy } \\
\text { coalitions/legitimization }\end{array}$ & $\begin{array}{l}\text { Advocating for indigenous RETs projects in remote communities. } \\
\text { Statements of indigenous leadership on the cultural fit of RETs projects. } \\
\text { Community visions and expectations favoring RETs deployment. }\end{array}$ \\
\hline
\end{tabular}

Data on the blocking mechanisms were collected through interviews with members of a remote indigenous community and a systematic review of academic and policy documents. The semi-structured interviews with 10 key informants, members of a remote northern Ontario community actively pursuing RETs projects, were conducted in October 2014. Interviews were undertaken following the Tri-Council policy requirements and received ethics clearance from the Office of Research Ethics at the University of Waterloo. Participants were proposed by the Band Council, were over 18 years old and consented in writing and to be interviewed orally. Secondary data were collected through a search in Scopus and Web of Science databases of the keywords: "renewable" AND "electricity" AND "barriers" AND "indigenous" AND "Canada", which returned 113 and 12 documents respectively. After eliminating studies irrelevant to Canadian context, seven documents were related to Canadian remote indigenous communities, of which only one document discussed barriers to RETs implementation. The search was then extended to non-scholarly journals and the internet and 13 documents were identified, presented in Section 3.2, which described barriers to RET deployment into Canadian remote indigenous communities.

Data for the event analysis were collected through multiple literature reviews of academic and non-academic, policy, utilities and communities' literature. Event analysis included only events that signaled a change of state and communicated public importance [62]. A list of the events and their allocation to functions is presented in Tables A1 and A2 in Appendix A.

\section{Results}

\subsection{TIS Structure}

The NWT and Ontario TISs (see also References $[8,11]$ ) are defined through a niche component (a new technology or sociotechnical practice) and its supporting system [29]. The niche consists of a sociotechnical practice, defined as the deployment of existing RETs in remote communities by indigenous governments with the purpose of undertaking (partially or in full) the electricity generation functions currently performed by Crown corporations (state utilities), with the aim to 
improve community sustainability, and environmental and socioeconomic conditions. This deployment encompasses both the domestication and societal embedding of new technologies, as well as measures involved in selecting, designing, purchasing, commissioning, and installing [63,64] solar and wind turbine applications in remote indigenous community diesel systems, to create hybrid solutions that provide acceptable power quality and supply. The supporting system includes a network of actors and institutions that jointly interact and contribute to the RET deployment. In addition, the TIS is concerned with the associated administrative procedures (such as planning and permitting), institutional and organizational changes, and regulatory and fiscal arrangements that allow for indigenous ownership of the RET application and participation in the electricity generation process.

The deployment of RETs in NWT and Ontario can be represented as two different TISs, with different and shared participating actors and their networks, and subject to shared and non-shared institutions. Key stakeholders in electricity generation include local indigenous governments and residential consumers, the federal and provincial/territorial governments, utilities operating mostly at "arm's length" from provincial/territorial governments, governmental agencies, academic and research institutes, non-governmental organizations, and the private sector. Indigenous people are subject to specific governance structures (the Indian Act; Land Claims and Self Government processes) [65], lack market economies [66], have historically experienced high unemployment and low educational attendance levels [67-69], and most importantly, have specific cultural values and worldviews on economic development, environmental governance and resource exploitation [58,70,71].

In addition, community electrical systems are the joint responsibility of both federal and provincial governments, with the federal government responsible for capital upgrades of the electricity generation equipment, and the provincial government responsible for maintenance and operations [72]. Furthermore, high electricity generation costs are subsidized by both federal and provincial governments, through cross subsidies, and direct and indirect funding. Communities also exhibit similar challenges, such as housing shortages, environmental concerns, economic development needs $[4,71,73]$, competing and shifting Band Council interests and priorities, and fluctuations in federal and state funding [74]. Entrepreneurial ventures within remote communities are the sole responsibility of indigenous governments and Local Development Corporations (LDCs) that aim at activities that fulfill three main goals, namely, economic development (in the form of revenue generation and employment), cultural preservation (in the form of minimal impact of ventures on lands and waters, ecological wellbeing, traditions and culture), and self-governance (expressed through the use of local resources, participation in management, and ownership of assets supporting self-sufficiency and self-reliance) [75-79].

\subsection{TIS Functions Performance}

The successful deployment of RETs in Ontario and NWT indigenous communities will depend on a well-functioning TIS, influenced by the specific institutional setting and indigenous cultural, socioeconomic and self-governance considerations. The fulfillment of the TIS functions is influenced by the existence of blocking mechanisms. Table 4 presents the blocking mechanisms, identified through a review of academic and policy literature [22-24,80-89] and informants' interviews, and their influence on the different TIS functions. The performance of the functions is discussed below. 
Table 4. Key blocking mechanisms and their influence on the NWT and Ontario TIS functions.

\begin{tabular}{|c|c|}
\hline System Functions & Blocking Mechanisms \\
\hline F1. Entrepreneurial activity & $\begin{array}{l}\text {-Lack of capital/access to capital [22-24,80,82-84,86,87,89] and key } \\
\text { informants' interviews. } \\
\text {-Vested interests [84]. } \\
\text {-Lack of capacity (community expertise) }[23,81-85,87-89] \text { and key } \\
\text { informants' interviews. } \\
\text {-Infrastructural deficiencies }[81,86,89] \text {. }\end{array}$ \\
\hline F2. Knowledge development & $\begin{array}{l}\text {-Existing regulatory processes associated with electricity } \\
\text { generation }[23,81,84,88,89] \text { and key informants' interviews. } \\
\text {-Lack of legal/regulatory framework on RETs } \\
\text { deployment }[80,82,83,87,88] \text {. } \\
\text {-Lack of capacity (community expertise and energy } \\
\text { education) }[23,81-84,86-89] \text { and key informants' interviews. } \\
\text {-Lack of networks }[80,82,86] \text { and key informants' interviews. }\end{array}$ \\
\hline F3. Knowledge diffusion & $\begin{array}{l}\text {-Lack of capacity (community expertise and energy } \\
\text { education) }[23,81-84,86-89] \text { and key informants' interviews. } \\
\text {-Lack of networks }[80,81,86] \text { and key informants' interviews. }\end{array}$ \\
\hline F4. Guidance of the search & $\begin{array}{l}\text {-Existing regulatory processes associated with electricity } \\
\text { generation }[23,81,84,88,89] \text { and key informants' interviews. } \\
\text {-Vested interests }[84] . \\
\text {-Lack of capacity (community expertise and energy } \\
\text { education) }[23,81-84,86-89] \text { and key informants' interviews. } \\
\text {-Lack of networks }[80,82,86] \text { and key informants' interviews. }\end{array}$ \\
\hline F5. Market formation & $\begin{array}{l}\text {-Existing regulatory processes associated with electricity } \\
\text { generation }[23,81,84,88,89] \text { and key informants' interviews. } \\
\text {-Vested interests }[84] . \\
\text {-Subsidies }[80,81] .\end{array}$ \\
\hline F6. Mobilization of resources & $\begin{array}{l}\text {-Electricity planning considerations }[23,81,84,88,89] \text { and key } \\
\text { informants' interviews. } \\
\text {-Bureaucratic procedures [key informants' interviews]. } \\
\text {-Lack of capacity (community expertise and energy } \\
\text { education) }[23,81-84,86-89] \text { and key informants' interviews. }\end{array}$ \\
\hline $\begin{array}{l}\text { F7. Support from advocacy } \\
\text { coalitions/legitimization }\end{array}$ & $\begin{array}{l}\text {-Vested interests [83]. } \\
\text {-High capital (investment) costs and reliability concerns }[82,83,86,87,89] \\
\text { and key informants' interviews. }\end{array}$ \\
\hline
\end{tabular}

\subsubsection{Entrepreneurial Activity (F1)}

The communal character of indigenous communities, limitations under the Indian Act, and cultural perceptions on entrepreneurship point to LDCs as the appropriate business development entity for RET experimentation within indigenous communities [90]. Community-owned RET projects could provide electricity directly to community members, or power community buildings under net metering agreements, or generate renewable electricity from stand-alone projects, which can be sold to non-indigenous utilities that operate the local systems. Community entrepreneurial activities are hindered by the lack of community financial resources and technical expertise, infrastructural deficiencies and electricity generation regulations, as well as community interests favoring the continuation of diesel electricity generation.

\subsubsection{Knowledge Development (F2)}

Knowledge development of RET applications at the community level takes the form of understanding potential community socioeconomic and environmental impacts and benefits, identifying the availability of local renewable resources and potential generation sites, developing technical solutions and implementation techniques, as well as improving human capacity in terms of technical and managerial skills. The knowledge development function is blocked by existing regulatory processes associated with electricity generation and 
a lack of a governmental focus on addressing indigenous governance concerns through RET development. Furthermore, knowledge development and community knowledge development capabilities are blocked by limited linkages with other actors (e.g., academia and industry) and a lack of communal capacity to participate in renewable resources surveys and monitoring studies, feasibility studies, community energy plans, and small scale RET experiments.

\subsubsection{Knowledge Diffusion (F3)}

Knowledge diffusion involves the dissemination of information within and across multiple communities on the cultural appropriateness, adaptation to local needs, potential benefits, and implementation difficulties of RETs. Favorite methods for the diffusion of knowledge, information exchange, and learning facilitation in indigenous communities include the establishment of networks that enable community participation in meetings, conferences, workshops, charrettes, training of community members and promoting energy-related education. The knowledge diffusion function is blocked by limited linkages and inadequate networks between indigenous remote communities and specialists that can facilitate learning from established projects.

\subsubsection{Guidance of the Search (F4)}

The guidance of research function represents the selection process that evaluates innovative solutions and facilitates their adoption, while taking into consideration community priorities and concerns based on local sustainability and governance perspectives. Indigenous perspectives on RETs deployment include pursuing and articulating specific targets, policies, and regulatory and fiscal reforms and incentives to improve communities' electrical systems. Guidance of the search is blocked by the existing electricity generation regulatory framework, consisting of planning principles, regulations, electricity rates and subsidies, and lack of provincial targets and policies for the development of RETs. Furthermore, the function's performance is influenced by community vested interests and risk averse attitudes; lack of technical, managerial and financial capacity; as well as the lack of networks that could modify current community and governmental preferences through multiple interactions.

\subsubsection{Market Formation (F5)}

Since the deployment of RETs in remote communities has to compete with established diesel generation, a market for renewable electricity should be instigated [32]. The market formation function for new renewable electricity generation is blocked, first, by reliability and safety regulations due to technical constraints associated with the penetration level of renewables in isolated diesel systems [14,17]; and second, the isolated nature of local diesel electricity markets supported by multiple subsidies necessitates the availability of financial resources for the establishment of new schemes that would support indigenous ownership of RET projects and compensate for vested interests in diesel, while maintaining residential electricity prices at the present level. Regulatory and fiscal arrangements that allow local governments and LDCs to participate in the electricity generation process take the form of Independent Power Producers (IPP) policies and generation incentives in the form of Power Purchase Agreements (PPAs) and net metering agreements.

\subsubsection{Mobilization of Resources (F6)}

The high cost of RETs and lack of community resources necessitates financial, material and capacity support for their deployment [91]. Furthermore, mobilization of resources for new renewable electricity generation in the area of remote indigenous communities is influenced by uncertainty over future electricity demand growth. This results from community and industrial development, and a preference of both NWT and Ontario governments towards large scale, cost minimizing electricity generation options, such as hydroelectricity, in association with grid extensions to supply future mining projects $[92,93]$. 


\subsubsection{Support from Advocacy Coalitions/Legitimization (F7)}

The implementation of RET projects would have to overcome the resistance of established interests in diesel-generated electricity [94] and community consumers' concerns over reliability and increased costs $[88,95]$. Furthermore, inclusion of indigenous perspectives on the anticipated contribution of RETs in the governance of community electrical systems, and design of policies that provide sustainable environmental and socioeconomic benefits would allow for higher acceptance of RETs by indigenous people.

The underlying systemic and transformational problems responsible for the blocking mechanisms that influence the performance of functions in both TIS are analyzed in the next section.

\subsection{Systemic Problems Influencing the NWT and Ontario TIS Performance}

\subsubsection{Hard Institutional Problems}

Two main sets of formal institutions influence the guidance of the search, knowledge development, resource mobilization and market formation functions. First, the regulatory framework for the introduction of RETs, consisting of utilities' planning principles, technical, operational, and safety regulations, and existing rates and subsidies structures, is different in each province. The planning principles focus on energy security, affordability and reliability, reduction of environmental impacts and cost minimization [96], combined with business strategies aimed at electricity generation flexibility [92,97]. Technical, operational, and safety regulations relate to electricity services quality, since high RET penetration levels within local and isolated provincial grids are subject to balance and reliability considerations [14,98]. Furthermore, high electricity generation costs lead to differentiated electricity rates for residential and commercial/governmental consumers funded by provincial and federal subsidies. The height of direct electricity subsidies for residential customers in remote communities ranged between \$3.5 million in 2015-2016 in Yukon [99], to \$34 million in 2015 in British Columbia [100], and approximately \$34 million in 2013 for Rural or Remote Rate Protection (RRRP) contributions in Ontario [101,102]. Finally, total energy-related direct governmental subsidies in Nunavut were approximately $\$ 30$ million for 2012-2013 [103]. These subsidies make cost comparisons between diesel powered electricity and RET options difficult and further reduce the motivation for RET deployment.

Second, formal institutions related to property rights, governance under the Indian Act, and indigenous views on development are responsible for limited entrepreneurial activities. Lack of property rights limits the possibility for non-indigenous and indigenous private entrepreneurial activities within reserve lands [66], and hinders access to banking loans, since traditional land is not accepted as collateral for financing purposes [75,77]. In addition, all economic activities within reserves, including energy development, are subject to indigenous governments' environmental licensing and regulation authority, which promotes projects under careful interpretation of treaty and indigenous rights and community socioeconomic benefits $[103,104]$.

\subsubsection{Soft Institutional Problems}

The existence of soft (informal) institutions associated with social norms, values and culture [37] within indigenous communities influence multiple TIS functions, including guidance of the search, knowledge development and market formation. First, communities have established vested interests in diesel generation through LDCs that cooperate with utilities, acquire rents, and provide employment through diesel storage and distribution [94]. These community interests benefit from diesel dependency and influence market formation, legitimization and social acceptance of the TIS, thus limiting guidance for the search for alternative entrepreneurial activities [105]. Second, risk averse attitudes of indigenous governments may influence guidance of the search away from risky RET applications (such as wind and solar, due to the inherent intermittency of these resources). Third, a community focus on economic development guides indigenous governments' decisions towards grid electrification, 
since grid electricity is considered a low risk, reliable, and affordable alternative able to support productive community activities $[92,106]$.

\subsubsection{Interaction Problems}

Interaction problems are caused by the lack of information exchange and/or the quality/intensity of information exchange between actors, and primarily impact the following functions: guidance of the search, knowledge development and diffusion and legitimization of the TIS [33]. Although local governments maintain direct or indirect relationships with the federal and provincial governments, utilities, private firms and other communities through tribal, provincial, and national political affiliations and interprovincial networks, such as the Assembly of First Nations (AFN), it is apparent that the quality/intensity of interactions and communication between indigenous people and other actors involved in the TIS are affected by various issues.

First, type and extent of interactions with provincial governments are influenced by cultural/political differences based on indigenous views on resource-driven development, with community members divided between those favoring economic development, and those preferring traditional Indigenist approaches $[107,108]$. Many projects are opposed due to potential impacts on the community's way of life and traditional activities [109]. Second, issues of trust, past relationships, grievances, and land claim disputes, which in turn are affected by indigenous choice of negotiation tactics, compatibility of goals, group cohesion and government perception of the indigenous group, shape the interaction between indigenous people, governments, and private actors $[110,111]$. Third, interactions favoring RET deployment may be deterred due to local government established focus on (lock-in to) diesel technologies due to the stability of significant revenues provided by diesel vested interests [94]. Fourth, interactions may also be blocked due to the lack of intermediaries, such as mediating organizations and educational institutions that may act as "bridges" helping to surpass issues of trust between indigenous communities and governments, utilities, and the private sector. Interactions with communities that have already implemented RET projects are important, since the sharing of experiences and practices assists in the development of internal capacity to maximize benefits from the projects and legitimizes RETs [112,113].

\subsubsection{Capability and Infrastructural Problems}

Knowledge infrastructure within the TIS takes the form of specialized knowledge and expertise generated by universities, research institutes and industry, while financial infrastructure consists of supporting incentives, grants and subsidies [33]. At the community level, capability problems take the form of low administrative, managerial and technical capacity $[15,20,86]$. Lack of local expertise combined with risk avoidance attitudes influence RET-related guidance of the search, knowledge development and diffusion, and entrepreneurial experimentation. Furthermore, lack of physical infrastructure hinders RET implementation on reserves and erodes legitimization. Limited access during winter through a network of ice roads, year-round access by airplanes and/or barges, high accommodation, communication, and energy costs, and lack of specialized equipment (such as cranes) increase the investment cost of any project in remote communities, and necessitate the mobilization of state financial resources $[22,24,94]$.

\subsubsection{Transformational Failures}

Transformational failures [50] are responsible for the underperformance of the guidance of the search and knowledge development, and, in turn, the other TIS functions. Prior to 2000, indigenous participation in renewable electricity generation was minimal and RET project development and ownership were driven by cost considerations of utilities and provincial governments, pointing, therefore, to a lack of shared vision regarding the direction of the electrical system transformation process and a directionality failure. In addition, early governmental support through national energy efficiency policies revolved around tax write-off incentives and financial assistance for R\&D activities and implementation studies [114], instead of targeting the transformation of community 
electrical systems through engagement and support of indigenous self-governance aspirations in the form of community participation in the decision making and planning process, indicating, therefore, both a policy coordination and a reflexivity failure. Furthermore, limited joint learning processes between governments, utilities, and communities, as well as communities' human capacity issues [23,115], hindered learning processes on the potential environmental and socioeconomic benefits of the introduction of RETs, thus contributing to both reflexivity and demand articulation failures.

\subsection{Performance of the NWT and Ontario TIS between 2000 and 2016}

\subsubsection{The NWT TIS Performance}

(1) NWT policy intervention to address systemic problems

In NWT, policy intervention during the 2001-2016 period to support RET deployment was introduced through public workshops and energy charrettes that captured stakeholders' differing perspectives on the future of NWT's energy system and led to multiple reviews of energy and electricity-related targets and policies. This interactive approach allowed for reflexivity, directionality and indigenous demand articulation issues to be addressed. During the same period, energy policy coordination issues were ameliorated through the establishment of the Ministerial Energy Coordinating Committee (MECC) that periodically monitored policy coherence at the horizontal level (between sectoral policies) [116,117].

In addition, hard and soft institutional problems influencing multiple functions of the TIS were addressed through federal and territorial programs that were sequentially introduced. Initial programs emphasized capital cost reduction in RET projects, followed by programs focusing on capabilities improvements and network formation through RET-related studies, and technical and educational assistance. Finally, during the 2013-2016 period, regulatory and financial arrangements were introduced to support community owned electricity generation. Network failures were mitigated through the participation, to varied extents, of utilities, universities, research institutes, the private sector and supporting organizations in the development of RET studies and projects. NTPC, ARI, NGOs like Pembina, and non-governmental agencies like Arctic Energy Alliance (AEA), engaged in renewable resource monitoring and feasibility studies, policy recommendations, advisory services, and equipment deployment, and contributed to the direction of the search, knowledge development and diffusion, mobilization of resources, and legitimization of the TIS [84,118-121].

\section{(2) NWT TIS functional pattern (2001-2016)}

The functional build-up of the NWT TIS was initiated with the release of the first NWT Energy Strategy in 2001 (+F4). In the same year, the provincial RETCAP (2001-2003) and the federal Aboriginal and Northern Climate Change Program (ANCCP) (2001-2003) were launched (+F4) providing capital support for RET projects (+F6). These early actions were followed by the Aboriginal and Northern Community Action Program (ANCAP) (2003-2007), engaging indigenous communities to take action to reduce GHG emissions, through community energy planning, community capacity building and wind studies in the Arctic, and promoting collaboration between local, federal and territorial government, utility, education institutes, and renewable energy companies (+F6) $[24,122,123]$. As a result, feasibility studies for the installation of wind turbines were conducted between 2003 and 2006 for most of the remote indigenous communities $(+\mathrm{F} 2)$. However, results indicated that wind turbines were financially viable for a limited number of communities (-F4) [21]. In 2006, a demonstration solar application was installed in the community of Jean Marie $(+\mathrm{F} 1)$.

The NWT government's commitment to the use of sustainable energy sources was further established during the 2007-2011 period. In 2007, the 2007 Energy Plan and the 2007-2011 Greenhouse Gas Strategy were released, both targeting the development of renewable applications and reductions in territorial emissions $(+\mathrm{F} 4)[124,125]$. In the same year, the first conference on wind turbine systems for the electrification of diesel powered communities was organized bringing together communities, 
utilities, governments and private actors $(+\mathrm{F} 3)$ [126]. At the same time, the federal government launched the first phase of the ecoENERGY for Aboriginal and Northern Communities Program (EANCP) (2007-2011) funding RET project costs and renewable resource monitoring and feasibility studies (+F4, F6) [122,127], while the territorial government established CREF, as part of the Alternative Energy Technologies (AET) program for financially supporting RET project costs (+F4, F6) [128]. Furthermore, the territorial government initiated a dialogue with communities through the review of existing regulations, rates and subsidies for electricity $(+\mathrm{F} 4)$ and focused on the coordination of all activities targeting energy reduction through the establishment of a coordinating committee and the use of AEA as a one stop agency for the delivery of programs to the communities $(+\mathrm{F} 4)$. AEA conducted a significant number of energy planning projects during 2008-2015 and, following the latest technology developments, the Aurora Research Institute (ARI) initiated a new round of optimization studies on the feasibility of wind and solar applications (+F2, F3) [119] (see also References [20,21]). Continuous dialogue between stakeholders led to reviews of the electricity process in 2008, 2009 and 2010 [95-97,129], revealing community interest in participation in RET projects, and leading to a revised Energy Strategy and Greenhouse Gas Strategy in 2011 (+F4) [117,125]. By the end of the 2007-2011 period, 10 small scale solar projects had been installed in remote communities, bringing the total number of solar installations to $11(+\mathrm{F} 1)$ (Table 5).

Table 5. RET projects in NWT and Ontario.

\begin{tabular}{cccccc}
\hline \multirow{2}{*}{$\begin{array}{c}\text { Time } \\
\text { Period }\end{array}$} & $\begin{array}{c}\text { Time } \\
\text { Interval }\end{array}$ & $\begin{array}{c}\text { Installed } \\
\text { Projects }\end{array}$ & $\begin{array}{c}\text { Average Project } \\
\text { Capacity }\end{array}$ & $\begin{array}{c}\text { Installed } \\
\text { Projects }\end{array}$ & $\begin{array}{c}\text { Average Project } \\
\text { Capacity }\end{array}$ \\
\hline $2001-2006$ & 6 years & 1 & $1.3 \mathrm{~kW}$ & & \\
$2007-2011$ & 5 years & 10 & $4.1 \mathrm{~kW}$ & & \\
$2012-2013$ & 2 years & 10 & $16.6 \mathrm{~kW}$ & 3 & $19.3 \mathrm{~kW}$ \\
$2014-2016$ & 2 years & 8 & $31.9 \mathrm{KW}$ & 10 & $30.0 \mathrm{~kW}$ \\
Total & & 29 & & 13 & \\
\hline
\end{tabular}

During the subsequent 2012-2016 period, a new round of guidance of the search, knowledge development and mobilization of financial resources activities led to an increase in the number and the average capacity of community RET projects. By 2012, multiple theoretical and empirical contributions on remote microgrids technology had been developed globally [130]. In Canada, several new optimization studies on the feasibility of RETs in indigenous remote communities added to knowledge development (+F2) [18,131,132]. Furthermore, in 2012, the NWT government announced its 2012 Solar Energy Strategy and organized the 2012 Energy Charrette to engage communities in the electricity planning process (+F4) [133,134]. The second phase of EANCP (2011-2016) was launched in 2011 emphasizing RET deployment in remote indigenous communities in addition to the continuous financial support from CREF (+F6) and in 2013 the NWT government announced its 2013 Energy Plan, which included its commitment to a reflexive and collaborative policy development (+F4) [135]. Ten higher scale solar projects (16 kW average capacity) were installed in 2012 and 2013 (+F1).

The subsequent 2014-2016 period is characterized by the second Energy Charrette in 2014, where the impacts of previous targets and programs were discussed and further deployment of small scale renewable projects was emphasized $(+\mathrm{F} 2,+\mathrm{F} 4)[136,137]$. Specialized workshops and conferences were organized in Ontario and NWT (Wind-Diesel Workshop, 1-2 June 2009, Ottawa, ON; 1st Renewables in Remote Microgrids Conference, 25-26 June 2013, Toronto, ON; 2nd Renewables in Remote Microgrids Conference, 15-17 September 2015, Yellowknife, NWT) supporting knowledge diffusion and interactions between multiple actors, including indigenous governments $(+\mathrm{F} 3)$. In addition, regulatory arrangements were introduced in 2014-2015 in the form of net metering and IPP policies that allowed for indigenous communities to participate in the electricity generation process creating a market for indigenous owned 
RET projects (+F5) $[138,139]$. Eight higher scale (32 kW average capacity) projects were developed in 2014 and 2015, resulting in a total of 18 solar projects between 2012 and 2016.

Over the 2001-2016 period in which the NWT TIS evolved, a total of 29 solar projects with a total capacity of $464 \mathrm{~kW}$ were developed in 19 of the 25 diesel powered remote indigenous communities. Fourteen communities developed one solar project, three communities installed two solar systems, one community installed three solar plants and one community installed six projects [8].

\subsubsection{The Ontario TIS Performance}

(1). Ontario policy intervention to address systemic problems

In Ontario, policy intervention during the 2001-2016 period in favor of RET deployment included support for both off-grid RET projects and communities' connection to the provincial grid [93]. Reflexivity, directionality and indigenous demand articulation issues influencing the guidance of the search towards RET deployment were addressed by the Nishnawbe Aski Nation (NAN), Tribal Councils, and community leaderships expressing an interest for sustainable options to address community electricity needs $[72,140,141]$. Furthermore, in a similar process to NWT, systemic problems were addressed through sequentially introduced federal and provincial financial support for projects' capital costs, community training, and community-owned electricity generation. Network problems were improved through the participation of numerous actors, including governmental agencies (IESO, HORCI), NGOs, universities [142], and the private sector that cooperated with indigenous communities in R\&D activities related to microgrid planning, testing, and training [143]. Technical, educational, and training support for a number of projects was provided by Shibogama Technical Services [144], an indigenous company supporting the members of the Shibogama Tribal Council, while project deployment and installation of solar projects were performed by indigenous owned enterprises [145]. These indigenous driven RET ventures improved local knowledge, generated local employment, contributed to the legitimization of the TIS, and pointed to the importance of trusted intermediaries for successful project deployment [146,147].

\section{(2). Ontario TIS functional pattern (2001-2016)}

The functional build-up of the Ontario TIS started with the governmental commitment towards renewable electricity generation expressed in 2003 and was supported by both requests for proposals and the 2006 introduction of early feed-in-tariffs to attract investments in renewable electricity generation $(+F 4,+F 6)[148,149]$. Indigenous interest in renewable electricity generation and the connection of communities to the provincial grid to improve socioeconomic conditions was expressed in 2008 by NAN, the political organization representing Ontario's remote indigenous communities $(+\mathrm{F} 4)[72,141]$. In 2009, the government introduced the Green Energy and Green Economy Act (GEGEA), which included financial incentives for indigenous communities' participation in RET projects (+F4) [150]. In the same year, and parallel to the federal EANCP program, both the Aboriginal Loan Guarantee program (ALG) and the Aboriginal Energy Partnerships Program (AEPP) were established by the Independent Electricity System Operator (IESO) to support indigenous participation in both on-grid and off-grid RETs through the development of community energy plans, feasibility and technical studies, resource assessments and training (+F6) [151,152].

Furthermore, between 2010 and 2013, optimization studies examining the potential of wind applications in Ontario's remote communities were developed (+F2) [20,21] and the second phase of EANCP focusing on RETs for remote indigenous communities was introduced $(+\mathrm{F} 6)$. Knowledge exchange between academia, government, utilities, private sector and communities was facilitated through the organization of the NAN energy conference in 2012 [140], the first conference on renewable microgrids in Toronto in 2013 and the 2014 NOFNEC indigenous environmental conference (+F3). To support off-grid RET deployment, Hydro One Remote Communities Inc. (HORCI) (a subsidiary of Hydro One Inc., Toronto, ON, Canada), the utility serving 15 of the remote indigenous communities [153], introduced 
a net metering and stand-alone arrangement creating a market for local electricity generation (+F5) [154]. In 2013, two small scale solar projects and one wind turbine project were developed in three communities (19.3 kW average capacity), followed by 10 higher capacity projects ( $30 \mathrm{~kW}$ average capacity) installed between 2014 and $2016(+\mathrm{F} 1)$ (Table 5).

In total, as the Ontario TIS evolved from 2008 to 2016, $358 \mathrm{~kW}$ of RET were installed in 11 of the 25 diesel powered remote indigenous communities. Five projects were installed in HORCI serviced communities and six in communities operating as Independent Power Authorities (IPA). All projects were installed under net metering arrangements on electricity intensive buildings with a view to displacing full cost electricity, thereby reducing expenses of local governments.

However, during the same period a competing TIS was established, initiated with the governmental commitment of the connection of remote indigenous communities to the provincial grid and the electrification of future natural resources development in the Ring of Fire area $(+\mathrm{F} 4$ towards an alternative niche) [93]. Technical studies verified the feasibility and financial viability of the connection of 21 of the 25 remote communities (+F2, alternative TIS) [155-157], and led to the prioritization of the grid connection project in the 2013 update of Ontario's LTEP (+F4, alternative TIS), and, in turn, the participation of 21 remote indigenous communities in the establishment of the transmission company Wataynikaneyap Power that will connect the communities to the provincial grid and provide electricity to mining projects in the Ring of Fire area (+F1, alternative TIS) [158].

\section{Discussion}

The relationship between the functional performance and the diffusion rates of RET projects is discussed in terms of presence and intensity of functions, and the existence of interactions between functions [31].

The analysis of the NWT and Ontario TISs demonstrates that the functional build-up during the investigated period shows a positive relationship to the number of RET projects developed and the transition toward more sustainable energy systems (Figure 1). In both TISs, the functional build-up is initiated with guidance of the search towards the introduction of RETs into community diesel systems followed by mobilization of financial resources, which are used to attract multiple actors, and the development of local knowledge through feasibility and resource monitoring studies. The results of these studies improved actors' learning on RET deployment, led to interactions between indigenous governments and other participants, and initiated a new round of guidance of the search, mobilization of resources, knowledge development and diffusion. Eventually, regulatory and fiscal arrangements were negotiated for the formation of local markets and the installation of higher capacity solar applications on community buildings. In NWT, the larger scale Colville Lake project [159], and the community-owned Lutselk'e solar plant that operates as an IPP producer, contribute further to the legitimization of the TIS [121,160], and signal an interest among communities towards higher renewable penetration projects under IPP ownership. The integration of higher penetration RET projects into isolated diesel power plants (measured through the ratio of the renewable component output $(\mathrm{kW})$ over the primary community electrical load $(\mathrm{kW})$ (instantaneous penetration) and the ratio of the renewable component energy output $(\mathrm{kWh})$ over the community electricity generation output (kWh) (average penetration) [14]) is associated with increased technical complexity of control devices for maintaining acceptable power quality, higher reductions in diesel consumption, and higher, but riskier, financial returns. Subsequent new governmental targets for RET deployment in remote communities [161-163], and the search for new financial mechanisms [164] indicates positive feedbacks between functions and a virtuous cycle characterizing the TIS development.

However, in Ontario, although the interaction of functions led to the functional build-up and entrepreneurial activities within a shorter time frame than in NWT, the functional performance was interrupted by a shift of community interest to a competing alternative [165], namely the potential connection to the provincial grid (new guidance of the search). The new alternative was embraced by communities who anticipate increased socioeconomic benefits through their participation in 
Wataynikaneyap Power. As a result, high capacity off-grid electrification projects are expected only for the remaining four communities that are unable to connect [166].
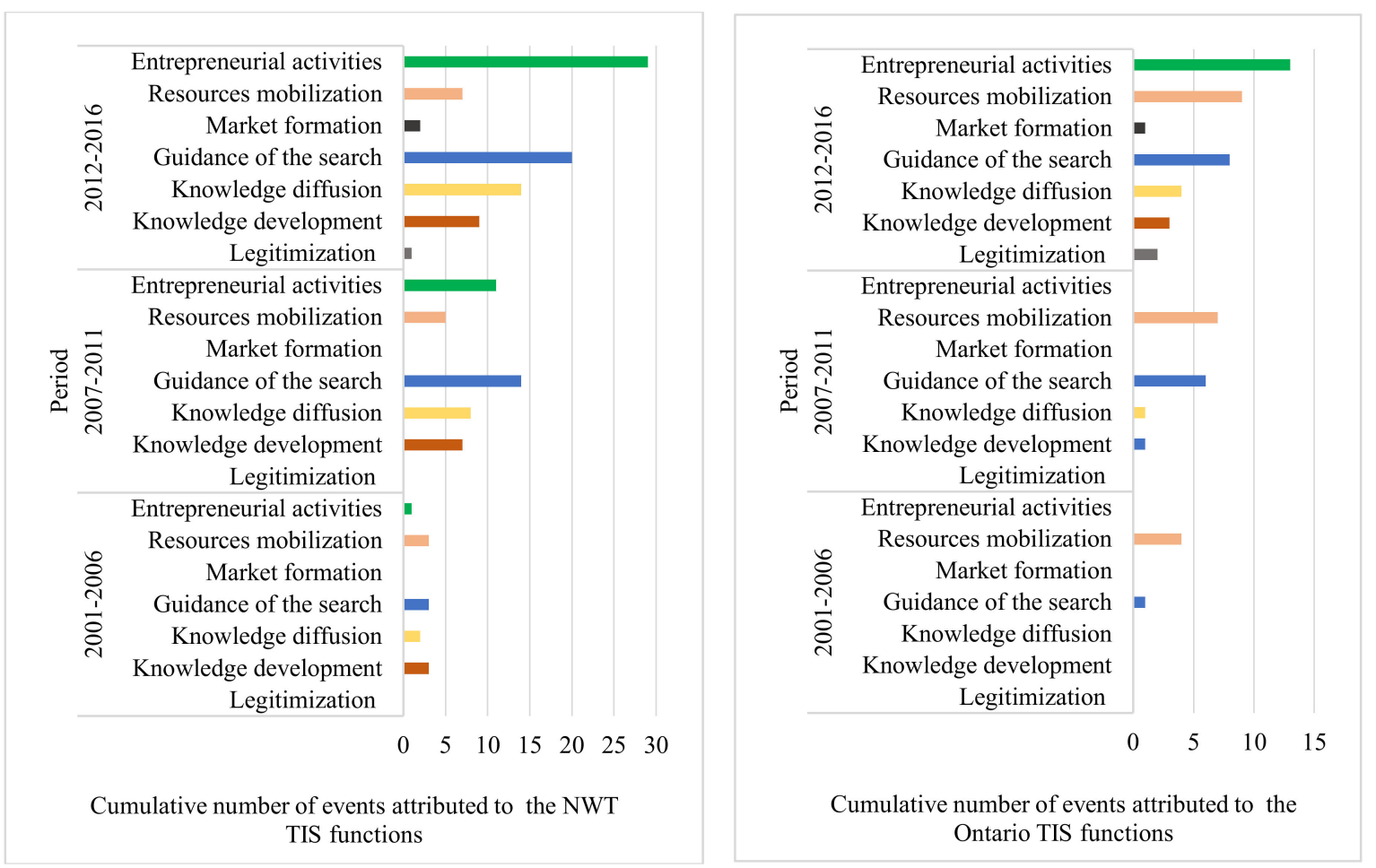

Figure 1. Accumulation of functions and RET projects developed in the NWT and Ontario TIS. Source: Data from Tables A1 and A2 in Appendix A.

These results are consistent with the results of References $[48,55]$ that report a positive relationship between the diffusion of RET products and projects and functional intensity in developing countries.

Results also point to three policy-related implications. First, the system-building functions in both TISs, as demonstrated by their strength, are guidance of the search and knowledge development. The functional build-up is initiated with actors' shared interest towards renewable solutions and, given the availability of financial resources, the development of knowledge for the introduction of RET into community electricity systems. Knowledge development in turn engages a significant number of actors in studies and experiments that improve and diffuse knowledge on the deployment of RET. The functional pattern in both TISs consists of successive "morphogenetic rounds" of guidance of the search, mobilization of resources, knowledge development and diffusion, which, eventually, lead to new guidance of the search for ownership of higher capacity and complexity RET projects [36] (p. 96).

Second, results point to the importance of financial resources mobilization for both the initiation of the functional build-up and the improvement of the functional performance, given the high investment costs and the limited financial, technical and managerial capacity of indigenous communities. NWT has spent approximately \$21 million on studying renewable energy applications for remote communities [167] and the federal government provided, between 2003 and 2016, \$65 million through ANCAP and EANCP for knowledge development on the feasibility assessment and integration of RETs into indigenous communities [168].

Third, a comparison between the NWT and Ontario TIS and the rest of the provinces and territories suggests that the system building functions (guidance of the search and knowledge development) are influenced by local institutional factors. Guidance of the search is influenced by the alignment of federal and provincial governments and utilities perspectives with indigenous aspirations to participate in the electricity decision making process, as demonstrated through NWT's multiple electricity reviews, and in Ontario, through the adoption of the NAN agenda on both off-grid and on-grid participation in 
RETs. In addition, the performance of the knowledge development function in both TISs is influenced by the existence of local educational and research facilities (universities, research institutes and local agencies) that conducted specialized research, engaged communities in development and installation of RET projects, and contributed to "learning by searching" and "learning by doing" [54].

Finally, functions and the functional build-up in both TISs benefitted from the evolution of a localized network that was formed to promote the deployment of RETs in remote indigenous communities by addressing interaction and transformational failures. These formal networks, consisting of local actors (provincial government, utilities, communities, educational and research facilities, NGOs), but also the federal government and national scale NGOs (Pembina) as well as private firms (Bullfrog Power), were able to build trust and shared expectations, and improve local skills and knowledge through learning processes [146] in order to access, develop and deploy resources in a more effective way than other provinces and territories $[169,170]$.

The importance of the functional build up for the diffusion of RET projects is demonstrated by the lack of such projects in Nunavut, Quebec and Newfoundland and Labrador indigenous communities during the 2000-2016 period. In Nunavut, despite early guidance of the search towards RETs [171] and knowledge development in the form of studies conducted between 2001 and 2009 [172,173], reduced availability of renewable resources (wind, solar and hydro), poor legitimization due to the failure of previous wind projects [174], as well as lack of financial resources from the government of Nunavut and QEC, blocked RETs deployment from 2001 to 2016 [175]. In Quebec, although early guidance of the search for community RETs led to a number of studies financed by Hydro-Quebec [176], diverging and competing community priorities (grid connection and hydroelectricity generation) limited development to only one wind project over the 2001-2016 period [177-179]. Finally, no RET projects were developed in Newfoundland and Labrador between 2001 and 2016, due to a lack of interest towards community RETs from provincial and indigenous governments, and limited commitment of financial resources towards feasibility studies on community wind, solar and hydroelectricity options [131].

\section{Concluding Remarks}

The aim of this paper was, first, to explain the diffusion of RET applications in remote indigenous communities in NWT and Ontario by analyzing the performance of the technological innovation systems, and, second, to identify factors that have the potential to sustain the development of these RET projects. The analysis shows that between 2000 and 2016, policies and programs in both jurisdictions addressed systemic and transformational failures, which allowed for the accumulation of TIS functions, which, in turn, led to the deployment of solar projects in the communities. In addition, the analysis points to the guidance of the search and knowledge development functions as the driving forces for the build-up of the functional system. The NWT innovation system case suggests that a highly inclusive and reflexive policy design initiated by the territorial government for addressing the energy needs of the isolated territory, as well as the establishment and support of a local network, contributed to the uptake of the innovation system. In the case of Ontario, guidance of the search was driven by indigenous communities' focus on RET projects, while the functional build-up evolved over a shorter period of time than NWT, as it benefitted from both knowledge developed in NWT and the establishment of a network of actors. Furthermore, the study also shows that, given the financial constraints present in most indigenous communities, governmental support is decisive for improving actors' presence, capabilities and interactions, and the creation of market formation mechanisms necessary for the undertaking of entrepreneurial activities.

The results confirm that the TIS approach can be used to study the diffusion of technological innovations in the specific institutional setting characterizing remote indigenous communities. Recent legal decisions prioritizing indigenous perspectives, lack of a market economy, and an indigenous focus on economic development, environmental protection, and self-governance signals that the determinants of RET diffusion are more complex than simple technoeconomic factors. Within the communities, locally owned RET projects 
are blocked by multiple institutional, capacity and infrastructural barriers that hinder their development. These systemic failures can be addressed through the functional approach proposed by the TIS.

In addition, the analysis of the functional evolution reveals that local governments and band councils engage in RET entrepreneurial ventures by (1) taking advantage of a sequence of events initiated by the provincial and territorial governments' interest in the use of renewable energy to reduce carbon emissions and electricity generation costs, and the availability of financial support for resource monitoring and feasibility studies contributing to the guidance of the search and knowledge development and diffusion; (2) learning through searching, training, and experimenting from projects installed in communities; and through engaging with numerous actors to improve knowledge on the specific applications and their potential to contribute to indigenous goals; and (3) modifying and articulating their perspectives, based on accumulated learning, towards RETs policies and programs that are supportive of indigenous aspirations and sustainability goals.

Furthermore, results suggest that, given the "system building" nature of the functions guidance of the search and knowledge development for community entrepreneurial activities, the aim of federal, provincial/territorial and indigenous governments should be policies targeting systemic and transformational problems (capabilities and interaction failures) that block these functions. Policy intervention for network building, capabilities improvements and knowledge development through experimenting with RETs will support further learning and empower indigenous communities and participating actors, enable them to adjust their perspectives and articulate policy direction according to their values and beliefs, and strengthen their governance structures. Accordingly, further research should, first, investigate local learning processes $[64,180]$ in the environment of remote indigenous communities in terms of who, how, and what is learned related to RET deployment. Second, given that knowledge development and diffusion are facilitated by local networks, further research could focus on both the role that community leadership and trusted local intermediaries play in the definition of the guidance of the search and knowledge development and diffusion, as well as their strategies for guiding the build-up of local TIS functions.

Author Contributions: K.K.: conceptualization, methodology, analysis, writing. P.P.: review, editing, supervision.

Funding: Funding support for this work was provided by Waterloo Institute of Sustainable Energy, Energy Council of Canada, and Natural Resources Canada. The funding organizations did not have any role in the creation, design, or writing of this research.

Acknowledgments: The Waterloo Institute of Sustainable Energy, Energy Council of Canada, and Natural Resources Canada supported this work. Valuable work on related topics by graduate students and other members of the Sustainable Energy Policy group at the University of Waterloo also helped to inform thinking in this area. The authors are grateful for this support; they, however, remain solely responsible for the contents of this article.

Conflicts of Interest: The authors declare no conflict of interest.

\begin{tabular}{ll}
\multicolumn{2}{l}{ Abbreviations } \\
AANDC & Aboriginal Affairs and Northern Development \\
AEA & Arctic Energy Alliance (AEA) \\
AEPP & Aboriginal Energy Partnerships Program \\
ALGP & Aboriginal Loan Guarantee Program \\
ANCAP & Aboriginal and Northern Community Action Program \\
ANCCP & Aboriginal and Northern Climate Change Program \\
ARI & Aurora Research Institute \\
GEGEA & Green Energy and Green Economy Act \\
CREF & Community Renewable Energy Fund \\
EANCP & Aboriginal and Northern Communities Program \\
HORCI & Hydro One Remote Communities Inc \\
IESO & Independent Electricity System Operator \\
INAC & Indigenous and Northern Affairs Canada
\end{tabular}




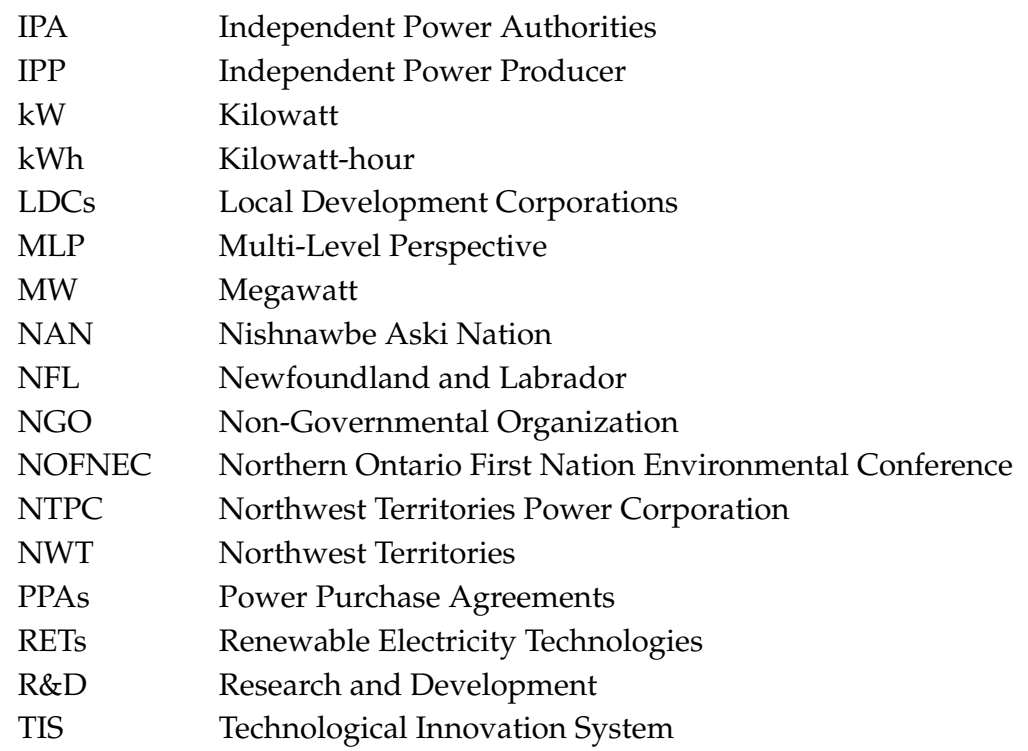

\section{Appendix A}

Table A1. Main events and events' allocation to functions for the NWT TIS.

\begin{tabular}{|c|c|c|}
\hline Year & Event & Function \\
\hline 1998 & GNWT Official Statement on Climate [116]. & Guidance of the search \\
\hline 1998 & Establishment of Arctic Energy Alliance (AEA). & $\begin{array}{l}\text { Guidance of the search } \\
\text { Knowledge development }\end{array}$ \\
\hline 2001 & $\begin{array}{l}\text { Aboriginal and Northern Climate Change Program (ANCCP) } \\
(2001-2003)[122,181] .\end{array}$ & Resources mobilization \\
\hline 2001 & $\begin{array}{l}\text { RETCAP (2001-2003): provincial program providing } 50 \% \text { rebates for } \\
\text { equipment and system balance costs. }\end{array}$ & Resources mobilization \\
\hline 2001 & A Greenhouse Gas Strategy for the Northwest Territories [125]. & Guidance of the search \\
\hline 2003 & $\begin{array}{l}\text { Aboriginal and Northern Community Action Program (ANCAP) } \\
(2003-2007)[122,181] .\end{array}$ & Resources mobilization \\
\hline 2003 & $\begin{array}{l}\text { Feasibility studies for wind projects for Sachs Harbour, Tuktoyaktuk, } \\
\text { Holman, and Paulatuk [182]. }\end{array}$ & $\begin{array}{l}\text { Knowledge development } \\
\text { Guidance of the search }\end{array}$ \\
\hline 2003 & $\begin{array}{l}\text { Feasibility studies for wing projects for Sachs Harbour, Ulukhaktok, } \\
\text { Paulatuk, Tuktoyaktuk, Yellowknife, Inuvik [183]. }\end{array}$ & $\begin{array}{l}\text { Knowledge development } \\
\text { Guidance of the search } \\
\text { Knowledge diffusion }\end{array}$ \\
\hline 2006 & $\begin{array}{l}\text { Feasibility studies for wind projects for } 31 \text { communities } \\
\text { in NWT }[172,173] \text {. }\end{array}$ & $\begin{array}{l}\text { Knowledge development } \\
\text { Guidance of the search } \\
\text { Knowledge diffusion }\end{array}$ \\
\hline 2006 & Jean Marie FN solar photovoltaic demonstration project. & Entrepreneurial activities \\
\hline 2007-2011 & $\begin{array}{l}\text { ecoENERGY for Aboriginal and Northern Communities Program } \\
\text { (EANCP) (Phase 1: 2007-2011) [127,168]. }\end{array}$ & Resources mobilization \\
\hline $2007-2016$ & $\begin{array}{l}\text { CREF (2007-todate) as part of the Alternative Energy Technologies } \\
\text { (AET) program providing funding for RETs projects costs [128]. } \\
\text {-Energy for the future-An Energy Plan for the Northwest Territories }\end{array}$ & Resources mobilization \\
\hline 2007 & $\begin{array}{l}\text {-A Greenhouse Gas Strategy for the Northwest Territories } \\
2007-2011[124,125] .\end{array}$ & Guidance of the search \\
\hline 2007 & Remote Community Wind Energy Conference Tuktoyaktuk [126]. & Knowledge diffusion \\
\hline 2007-2016 & $\begin{array}{l}\text { CREF (2007-todate) as part of the Alternative Energy Technologies } \\
\text { (AET) program providing funding for RETs projects costs. }\end{array}$ & Mobilization of resources \\
\hline 2008 & $\begin{array}{l}\text {-2008: Energy priorities framework-Ministerial Energy Coordinating } \\
\text { Committee (MECC). } \\
\text {-2008: Review of Electricity Regulation, Rates and Subsidy Programs } \\
\text { in the Northwest Territories }[96,116] \text {. }\end{array}$ & Guidance of the search \\
\hline
\end{tabular}


Table A1. Cont.

\begin{tabular}{|c|c|c|}
\hline Year & Event & Function \\
\hline 2008-2015 & $\begin{array}{l}\text { Feasibility studies for wind and solar projects for Colville Lake, } \\
\text { Deline, Jean Marie River, Trout Lake, and Fort Providence } \\
\text { in NWT }[119,184] \text {. }\end{array}$ & $\begin{array}{l}\text { Knowledge development } \\
\text { Guidance of the search } \\
\text { Knowledge diffusion }\end{array}$ \\
\hline 2008 & $\begin{array}{l}\text { Optimization studies for wind projects for } 12 \text { communities } \\
\text { in NWT [20]. }\end{array}$ & $\begin{array}{l}\text { Knowledge development } \\
\text { Guidance of the search } \\
\text { Knowledge diffusion }\end{array}$ \\
\hline 2008-2015 & $\begin{array}{l}\text { Community energy profiles: community energy planning activities } \\
\text { by AEA [118]. }\end{array}$ & $\begin{array}{l}\text { Knowledge development } \\
\text { Guidance of the search } \\
\text { Knowledge diffusion }\end{array}$ \\
\hline 2009 & $\begin{array}{l}\text {-Electricity review. A discussion with northerners about electricity. } \\
\text {-Creating a brighter future: a review of electricity regulation, rates } \\
\text { and subsidy programs in the northwest territories }[95,129] .\end{array}$ & Guidance of the search \\
\hline 2009 & $\begin{array}{l}\text { Inuvik: development of two small scale solar photovoltaic projects. } \\
\text { Efficient, Affordable and Equitable: Creating a Brighter Future for }\end{array}$ & Entrepreneurial activities \\
\hline 2010 & $\begin{array}{l}\text { the Northwest Territories' Electricity System. Response to the } 2008 \\
\text { and } 2009 \text { NTPC review [97]. }\end{array}$ & Guidance of the search \\
\hline 2010 & Optimization studies for wind projects for 12 communities in NWT [21]. & Knowledge development \\
\hline 2010 & $\begin{array}{l}\text { Development of solar projects in Sachs Harbour and Wekweètì. } \\
\text {-NWT energy report. Report of Ministerial Energy Coordinating }\end{array}$ & Entrepreneurial activities \\
\hline 2011 & $\begin{array}{l}\text { Committee (MECC). } \\
\text {-2011: A Greenhouse Gas Strategy for the Northwest Territories } \\
\text { 2011-2015 [117,125]. }\end{array}$ & Guidance of the search \\
\hline 2011 & $\begin{array}{l}\text { AEA: Publishing the "Best energy practices for remote } \\
\text { facilities" guide [185]. }\end{array}$ & $\begin{array}{l}\text { Knowledge development } \\
\text { Guidance of the search } \\
\text { Knowledge diffusion }\end{array}$ \\
\hline 2011 & $\begin{array}{l}\text { Development of solar projects in Nahanni Butte, Norman Wells, } \\
\text { Paulatuk (two projects) and Inuvik (two projects). }\end{array}$ & Entrepreneurial activities \\
\hline 2011 & AANDC and NRCAN publication: Status of remote communities [5]. & $\begin{array}{l}\text { Guidance of the search } \\
\text { Knowledge diffusion }\end{array}$ \\
\hline 2012-2016 & $\begin{array}{l}\text { ecoENERGY for Aboriginal and Northern Communities Program } \\
\text { (EANCP) (Phase 2: 2012-2016) 2011) [127]. }\end{array}$ & Mobilization of resources \\
\hline 2012-2015 & $\begin{array}{l}\text { Community energy profiles: community energy planning activities } \\
\text { by AEA [118]. }\end{array}$ & $\begin{array}{l}\text { Knowledge development } \\
\text { Guidance of the search } \\
\text { Knowledge diffusion }\end{array}$ \\
\hline 2012 & Development of solar projects in in Gameti and Whati. & Entrepreneurial activities \\
\hline 2012 & Northwest Territories Solar Energy Strategy 2012-2017 [133]. & Guidance of the search \\
\hline 2012 & NWT Energy Charette [134]. & $\begin{array}{l}\text { Knowledge diffusion } \\
\text { Guidance of the search }\end{array}$ \\
\hline 2013 & $\begin{array}{l}\text { Development of solar projects in Fort Good Hope, Fort Providence, } \\
\text { Fort Simpson (three projects), Inuvik (two projects), and Tulita. }\end{array}$ & Entrepreneurial activities \\
\hline 2013 & The NWT Energy Action Plan [135]. & Guidance of the search \\
\hline 2014 & Development of a solar project in Fort Liard. & Entrepreneurial activities \\
\hline 2014 & NWT Energy Charette [186]. & $\begin{array}{l}\text { Knowledge diffusion } \\
\text { Guidance of the search }\end{array}$ \\
\hline 2014 & NTPC net metering [138]. & Market formation \\
\hline 2015 & $\begin{array}{l}\text { IPP policy and net metering policy for aboriginal } \\
\text { community projects [138]. }\end{array}$ & Market formation \\
\hline 2015 & 2nd Renewables in Remote Microgrids conference [164]. & Knowledge diffusion \\
\hline 2015 & GNWT response to the 2014 NWT energy charrette report [137]. & Knowledge diffusion \\
\hline 2015 & $\begin{array}{l}\text { Development of solar projects in Aklavik, Colville Lake, Gameti, } \\
\text { Lutselk'e, Tsiigehtchic, Whati, and Wringley-Pehdzeh Ki FN. }\end{array}$ & Entrepreneurial activities \\
\hline 2016 & NWT-Energy strategy discussion [162]. & Guidance of the search \\
\hline 2016 & CBC announcements for RET indigenous projects [121,159-161]. & Legitimization \\
\hline
\end{tabular}


Table A2. Main events and events' allocation to functions for the Ontario TIS.

\begin{tabular}{|c|c|c|}
\hline Year & Event & Function \\
\hline 2001 & $\begin{array}{l}\text { Aboriginal and Northern Climate Change Program (ANCCP) } \\
(2001-2003)[122,181] .\end{array}$ & Mobilization of resources \\
\hline 2003 & $\begin{array}{l}\text { Aboriginal and Northern Community Action Program (ANCAP) } \\
(2003-2007)[122,181] .\end{array}$ & Mobilization of resources \\
\hline 2003 & Governmental commitments for renewable electricity generation. & Guidance of the search, \\
\hline 2004-2005 & $\begin{array}{l}\text { Call for proposal and request for proposals for renewable } \\
\text { electricity generation [148]. }\end{array}$ & Mobilization of resources \\
\hline 2006 & $\begin{array}{l}\text { RESOP, Feed-in-tariffs and net metering policies for renewable } \\
\text { electricity introduced [148]. }\end{array}$ & Mobilization of resources \\
\hline 2007-2011 & $\begin{array}{l}\text { ecoENERGY for Aboriginal and Northern Communities Program } \\
\text { (EANCP) (Phase 1: 2007-2011) [127,168]. }\end{array}$ & Mobilization of resources \\
\hline 2008 & OEB (talks about the communities' goals and the NAN) [72]. & Guidance of the search \\
\hline 2009 & GEGEA Act [149]. & Guidance of the search \\
\hline 2009 & Aboriginal Loan Guarantee Program (ALG) [151]. & Mobilization of resources \\
\hline 2009 & Aboriginal Energy Partnerships Program (AEPP) [152]. & Mobilization of resources \\
\hline 2010 & 2010 Ontario's LTEP [93]. & Guidance of the search \\
\hline 2010 & $\begin{array}{l}\text { OPA: Draft technical report for the connection of } \\
\text { remote communities [155]. }\end{array}$ & Guidance of the search \\
\hline 2010 & $\begin{array}{l}\text { Optimization studies for wind projects for } 16 \text { communities } \\
\text { in Ontario }[20,21]\end{array}$ & Knowledge development \\
\hline 2011 & AANDC and NRCAN publication: Status of remote communities [5]. & $\begin{array}{l}\text { Guidance of the search } \\
\text { Knowledge diffusion }\end{array}$ \\
\hline 2012-2016 & $\begin{array}{l}\text { ecoENERGY for Aboriginal and Northern Communities Program } \\
\text { (EANCP) (Phase 2: 2012-2016) [122,181] }\end{array}$ & Mobilization of resources \\
\hline 2012 & NAN Energy conference [187]. & Knowledge diffusion \\
\hline 2013 & Optimization study for Kasabonika Lake First Nation [18]. & Knowledge development \\
\hline 2013 & $\begin{array}{l}\text { REINDEER program (a HORCI communities' diesel } \\
\text { displacement incentive) [154]. }\end{array}$ & Market formation \\
\hline 2013 & 2013 Ontario's LTEP [93]. & Guidance of the search \\
\hline 2013 & 1st Remote Microgrids Conference in Toronto. & Knowledge diffusion \\
\hline 2013 & $\begin{array}{l}\text { Development of two solar projects in Kingfisher FN and Wawakapewin } \\
\text { FN and one wind turbine project in Kasabonika Lake FN. }\end{array}$ & Entrepreneurial activities \\
\hline 2014 & $\begin{array}{l}2014 \text { Northern Ontario First Nations Environmental } \\
\text { Conference (NOFNEC). } \\
\text { IESO programs launched: Aboriginal Transmission Fund (ATF), }\end{array}$ & Knowledge diffusion \\
\hline 2014 & $\begin{array}{l}\text { Remote Electrification Readiness Program, Education and Capacity } \\
\text { Building (ECB) Program [188]. }\end{array}$ & Mobilization of resources \\
\hline 2014 & $\begin{array}{l}\text { Development of two solar projects in Deer Lake FN, and one solar } \\
\text { project in Kasabonika Lake FN. }\end{array}$ & Entrepreneurial activities \\
\hline 2014 & Indigenous press on the development of a solar project in Deer Lake [189]. & Legitimization \\
\hline 2014 & NCC press announcements on indigenous projects [144]. & Legitimization \\
\hline 2014 & IESO: Draft technical report for the connection of remote communities [154]. & Guidance of the search \\
\hline 2015 & $\begin{array}{l}\text { Development of solar projects in Fort Severn FN, Keewaywin FN, North } \\
\text { Spirit Lake FN, Poplar Hill FN, Muskrat Dam FN, and Weenusk FN. }\end{array}$ & Entrepreneurial activities \\
\hline 2016 & Development of a solar project in North Karibou Lake FN. & Entrepreneurial activities \\
\hline 2016 & Optimization study for Kasabonika Lake First Nation [19]. & Knowledge development \\
\hline
\end{tabular}

\section{References}

1. Walker, G.; Devine-Wright, P. Community renewable energy: What should it mean? Energy Policy 2008, 36, 497-500. [CrossRef]

2. Seyfang, G.; Smith, A. Grassroots Innovations for Sustainable Development: Towards a New Research and Policy Agenda. Environ. Politics 2007, 16, 584-603. [CrossRef]

3. Forest, N.; Wiek, A. Success factors and strategies for sustainability transitions of small-scale communities-Evidence from a cross-case analysis. Environ. Innov. Soc. Transit. 2015, 17, 22-40. [CrossRef]

4. AANDC. Off-Grid Communities. 2012. Available online: https://www.aadnc-aandc.gc.ca/eng/1314295992771/ 1314296121126\#comm (accessed on 31 October 2017).

5. AANDC and NRCan. Status of Remote/Off-Grid Communities in Canada; Aboriginal Affairs and Northern Development Canada (AANDC) and Natural Resources Canada (NRCan): Ottawa, ON, Canada, 2011.

6. $\quad$ OECD. Linking Renewable Energy to Rural Development; OECD Publishing: Paris, France, 2012. 
7. Karanasios, K.; Parker, P. Recent Developments in Renewable Energy in Remote Aboriginal Communities, Yukon, Canada. Pap. Can. Econ. Dev. 2016, 16, 29-40.

8. Karanasios, K.; Parker, P. Recent developments in renewable energy in remote aboriginal communities, NWT, Canada. Pap. Can. Econ. Dev. 2016, 16, 41-53.

9. Karanasios, K.; Parker, P. Recent Developments in Renewable Energy in Remote Aboriginal Communities, Nunavut, Canada. Pap. Can. Econ. Dev. 2016, 16, 54-64.

10. Karanasios, K.; Parker, P. Recent Developments in Renewable Energy in Remote Aboriginal Communities, British Columbia, Canada. Pap. Can. Econ. Dev. 2016, 16, 65-81.

11. Karanasios, K.; Parker, P. Recent developments in renewable energy in remote aboriginal communities, Ontario, Canada. Pap. Can. Econ. Dev. 2016, 16, 82-97.

12. Karanasios, K.; Parker, P. Recent Developments in Renewable Energy in Remote Aboriginal Communities, Quebec, Canada. Pap. Can. Econ. Dev. 2016, 16, 98-108.

13. Karanasios, K.; Parker, P. Recent Developments in Renewable Energy in Remote Aboriginal Communities, Newfoundland and Labrador, Canada. Pap. Can. Econ. Dev. 2016, 16, 109-118.

14. Baring-Gould, I.; Corbus, D. Status of Wind-Diesel Applications in Arctic Climates. In Proceedings of the Arctic Energy Summit Technology Conference, NREL/CP-500-42401, Anchorage, Alaska, USA, 15-18 October 2007.

15. Fay, G.; Udovyk, N. Factors Influencing Success of Wind-Diesel Hybrid Systems in Remote Alaska Communities: Results of an Informal Survey. Renew. Energy 2013, 57, 554-557. [CrossRef]

16. Fay, G.; Keith, K.; Schwörer, T. Alaska Isolated Wind-Diesel Systems: Performance and Economic Analysis; Alaska Energy Authority: Anchorage, AK, USA, 2010.

17. Tan, Y.; Meegahapola, L.; Muttaqi, K. A review of technical challenges in planning and operation of remote area power supply systems. Renew. Sustain. Energy Rev. 2014, 38, 876-889. [CrossRef]

18. Arriaga, M.; Cañizares, C.; Kazerani, M. Renewable Energy Alternatives for Remote Communities in Northern Ontario, Canada. IEEE Trans. Sustain. Energy 2013, 4, 661-670. [CrossRef]

19. Arriaga, M.; Cañizares, C.; Kazerani, M. Long-Term Renewable Energy Planning Model for Remote Communities. IEEE Trans. Sustain. Energy 2016, 7, 226-231. [CrossRef]

20. Weis, T.; Ilinca, A. The utility of energy storage to improve the economics of wind-diesel power plants in Canada. Renew. Energy 2008, 33, 1544-1557. [CrossRef]

21. Weis, T.; Ilinca, A. Assessing the potential for a wind power incentive for remote villages in Canada. Energy Policy 2010, 38, 5504-5511. [CrossRef]

22. INAC. Sharing the Story: Aboriginal and Northern Energy Experiences; Indigenous and Northern Affairs Canada: Ottawa, ON, Canada, 2004.

23. INAC. Sharing the Story: Sustainable Initiatives in First Nation; Indigenous and Northern Affairs Canada: Ottawa, ON, Canada, 2005.

24. INAC. Reflections on Success. A Sustainable Future in a Changing Climate; Indigenous and Northern Affairs Canada: Ottawa, ON, Canada, 2007.

25. Rezaei, M.; Dowlatabadi, H. Off-grid: Community energy and the pursuit of self-sufficiency in British Columbia's remote and First Nations communities. Local Environ. Int. J. Justice Sustain. 2015, 21, 789-807. [CrossRef]

26. Geels, F. Technological Transitions and System Innovations; Edward Elgar Publishing Ltd.: Northampton, MA, USA, 2005.

27. Geels, F.; Schot, J. Typology of sociotechnical transition pathways. Res. Policy 2007, 36, 399-417. [CrossRef]

28. Karanasios, K.; Parker, P. Tracking the transition to renewable electricity in remote indigenous communities in Canada. Energy Policy 2018, 118, 169-181. [CrossRef]

29. Markard, J.; Truffer, B. Technological innovation systems and the multi-level perspective: Towards an integrated framework. Res. Policy 2008, 37, 596-615. [CrossRef]

30. Smith, A.; Stirling, A.; Berkhout, F. The governance of sustainable socio-technical transitions. Res. Policy 2005, 34, 1491-1510. [CrossRef]

31. Hekkert, M.; Suurs, R.; Negro, S.; Kuhlmann, S.; Smits, R. Functions of innovation systems: A new approach for analysing technological change. Technol. Forecast. Soc. Chang. 2007, 7, 413-432. [CrossRef]

32. Bergek, A.; Jacobsson, S.; Carlsson, B.; Lindmark, L.; Rickne, A. Analyzing the functional dynamics of technological innovation systems: A scheme of analysis. Res. Policy 2008, 37, 407-429. [CrossRef] 
33. Wieczorek, A.; Hekkert, M. Systemic instruments for systemic innovation problems: A framework for policy makers and innovation scholars. Sci. Public Policy 2012, 39, 74-87. [CrossRef]

34. Negro, S.; Hekkert, M.; Smits, R. Explaining the failure of the Dutch innovation system for biomass digestion. A functional analysis. Energy Policy 2007, 35, 925-938. [CrossRef]

35. Jacobsson, S.; Bergek, A. Transforming the energy sector: The evolution of technological systems in renewable energy technology. Ind. Corp. Chang. 2004, 13, 815-849. [CrossRef]

36. Grin, J.; Rotmans, J.; Schot, J. Transitions to Sustainable Development: New Directions in the Study of Long Term Transformative Change; Routledge: New York, NY, USA, 2010.

37. Woolthuis, R.; Lankhuizen, M.; Gilsing, V. A system failure framework for innovation policy design. Technovation 2005, 25, 609-619. [CrossRef]

38. Negro, S.; Alkemade, F.; Hekkert, M. Why does renewable energy diffuse so slowly? A review of innovation system problems. Renew. Sustain. Energy Rev. 2012, 16, 3836-3846. [CrossRef]

39. Jacobsson, S.; Bergek, A. A Framework for Guiding Policy-makers Intervening in Emerging Innovation Systems in 'Catching-Up' Countries. Eur. J. Dev. Res. 2006, 18, 687-707. [CrossRef]

40. Elzen, B.; Wieczorek, A. Transitions towards sustainability through system innovation. Technol. Forecast. Soc. Chang. 2005, 72, 651-661. [CrossRef]

41. Weber, K.; Rohracher, H. Legitimizing research, technology and innovation policies for transformative change. Combining insights from innovation systems and multi-level perspective in a comprehensive 'failures' framework. Res. Policy 2012, 41, 1037-1047. [CrossRef]

42. Avelino, F.; Rotmans, J. Power in Transition: An Interdisciplinary Framework to Study Power in Relation to Structural Change. Eur. J. Soc. Theory 2009, 12, 543-569. [CrossRef]

43. Meadowcroft, J. What about the politics? Sustainable development, transition management, and long term energy transitions. Policy Sci. 2009, 42, 323-340. [CrossRef]

44. Coenen, L.; Benneworth, P.; Truffer, B. Toward a spatial perspective on sustainability transitions. Res. Policy 2012, 41, 968-979. [CrossRef]

45. Binz, C.; Truffer, B.; Coenen, L. Why space matters in technological innovation systems-Mapping global knowledge dynamics of membrane bioreactor technology. Res. Policy 2014, 43, 138-155. [CrossRef]

46. Blum, N.; Bening, C.; Schmidt, T. An analysis of remote electric mini-grids in Laos using the Technological Innovation Systems approach. Technol. Forecast. Soc. Chang. 2015, 95, 218-233. [CrossRef]

47. Dewald, U.; Truffer, B. The Local Sources of Market Formation: Explaining Regional Growth Differentials in German Photovoltaic Markets. Eur. Plan. Stud. 2012, 20, 397-420. [CrossRef]

48. Markard, J.; Hekkert, M.; Jacobsson, S. The technological innovation systems framework: Response to six criticisms. Environ. Innov. Soc. Transit. 2015, 16, 76-86. [CrossRef]

49. Hillman, K.; Suurs, R.; Hekkert, M.; Sanden, B. Cumulative causation in biofuels development: A critical comparison of the Netherlands and Sweden. Technol. Anal. Strateg. Manag. 2008, 20, 593-612. [CrossRef]

50. Suurs, R.; Hekkert, M. Cumulative causation in the formation of a technological innovation system: The case of biofuels in the Netherlands. Technol. Forecast. Soc. Chang. 2009, 76, 1003-1020. [CrossRef]

51. Suurs, R.; Hekkert, M.; Kieboom, S.; Smits, R. Understanding the formative stage of technological innovation system development: The case of natural gas as an automotive fuel. Energy Policy 2010, 38, 419-431. [CrossRef]

52. Jacobsson, S. The emergence and troubled growth of a 'biopower' innovation system in Sweden. Energy Policy 2008, 36, 1491-1508. [CrossRef]

53. Hawkey, D. District heating in the UK: A Technological Innovation Systems analysis. Environ. Innov. Soc. Transit. 2012, 5, 19-32. [CrossRef]

54. Palm, A. An emerging innovation system for deployment of building-sited solar photovoltaics in Sweden. Environ. Innov. Soc. Transit. 2015, 15, 140-157. [CrossRef]

55. VanAlphen, K.; Hekkert, M.; VanSark, W. Renewable energy technologies in the Maldives-Realizing the potential. Renew. Sustain. Energy Rev. 2008, 12, 168-180.

56. Tigabu, A.; Berkhout, F.; van Beukering, P. The diffusion of renewable energy technology and innovation system functioning: Comparing bio-digestion in Kenya and Rwanda. Technol. Forecast. Soc. Chang. 2015, 90, 331-345. [CrossRef]

57. Kebede, K.; Mitsufuji, T. Diffusion of solar innovations in Ethiopia: Exploring systemic problems. Int. J. Technol. Manag. Sustain. Dev. 2014, 13, 53-72. [CrossRef] 
58. RCAP. Restructuring the Relationship-Royal Commission on Aboriginal Peoples-Volume 2, Chapter 5; Royal Commission on Aboriginal Peoples: Ottawa, ON, Canada, 1996.

59. Angell, A.; Parkins, J. Resource development and aboriginal culture in the Canadian north. Polar Rec. 2011, 47, 67-79. [CrossRef]

60. BCAFN. Governance Toolkit: A Guide to Nation Building_Part 1; British Columbia Assembly of First Nation: West Vancouver, BC, Canada, 2011; Available online: http://www.bcafn.ca/toolkit/pdf/Part1Tabs.pdf (accessed on 6 December 2014).

61. Labrinopoulou, C.; Renwick, A.; Klerkx, L.; Hermans, F.; Roep, D. Application of an integrated systemic framework for analysing agricultural innovation systems and informing innovation policies: Comparing the Dutch and Scottish agrifood sectors. Agric. Syst. 2014, 129, 40-54. [CrossRef]

62. Agbemabiese, L.; Nkomo, J.; Sokona, Y. Enabling innovations in energy access: An African perspective. Energy Policy 2012, 38, 38-47. [CrossRef]

63. Becker, S.; Kunze, C.; Vancea, M. Community energy and social entrepreneurship: Addressing purpose, organisation and embeddedness of renewable energy projects. J. Clean. Prod. 2017, 147, 25-36. [CrossRef]

64. Neij, L.; Heiskanen, E.; Strupeit, L. The deployment of new energy technologies and the need for local learning. Energy Policy 2017, 101, 274-283. [CrossRef]

65. Coates, K. The Indian Act and the Future of Aboriginal Governance in Canada; National Centre for First Nations Governance. 2008. Available online: http:/ / fngovernance.org/ncfng_research/coates.pdf (accessed on 14 December 2014).

66. Alcantara, C. Individual property rights on Canadian Indian Reserves: The historical emergence and jurisprudence of Certificates of Possession. Can. J. Nativ. Stud. 2003, 2, 391-424.

67. Southcott, C.; Walker, V. A Portrait of the Social Economy in Northern Canada. North. Rev. 2009, 30, $13-36$.

68. Wilson, D.; Macdonald, D. The Income Gap between Aboriginal Peoples and the Rest of Canada; Canadian Centre for Policy Alternatives: Ottawa, ON, Canada, 2010.

69. Loppie, C.; Wien, F. Health Inequalities and Social Determinants of Aboriginal Peoples' Health; National Collaborative Centre for Aboriginal Health: Prince George, BC, Canada, 2009.

70. IAND. Gathering Strength-Canada's Aboriginal Action Plan; Minister of Indian Affairs and Northern Development: Ottawa, ON, Canada, 1997.

71. AAWG. Report to Provincial and Territorial Ministers of Aboriginal Affairs and National Aboriginal Organization Leaders. 2010. Available online: www2.gov.bc.ca/assets/gov/environment/natural-resource stewardship/consulting-with-first-nations / first-nations / report_aboriginal_affairs_working_group.pdf (accessed on 31 October 2017).

72. OEB. Evidence of the Intervenor the Nishnawbi Aski Nation; Ontario Energy Board: Toronto, ON, Canada, 2008.

73. AAWG. Strengthening Aboriginal Participation in the Economy. Available online: http://www.turtleisland. org/business/economy.pdf (accessed on 5 February 2015).

74. INAC. Government of Canada Focuses Funding on Essential Programs and Services for Aboriginal Peoples. Indigenous and Northern Affairs Canada. Available online: https://www.canada.ca/en/news/archive/ 2012/09/government-canada-focuses-funding-essential-programs-services-aboriginal-peoples.html?= undefined\& (accessed on 31 October 2017).

75. OAG. Chapter 9. Economic Development of First Nations Communities: Institutional Arrangements; Office of the Auditor General: Ottawa, ON, Canada, 2003.

76. Cornell, S.; Kalt, J.P. Sovereignty and Nation-Building: The Development Challenge in Indian Country Today. Am. Indian Cult. Res. J. 2003, 22, 187-214. [CrossRef]

77. Anderson, R.; Dana, L.; Dana, T. Indigenous Land Rights, Entrepreneurship, and Economic Development in Canada: "Opting-in" to the Global Economy. J. World Bus. 2006, 41, 45-55. [CrossRef]

78. Senate Committee. Sharing Canada's Prosperity—A Hand Up, Not a Handout; Standing Senate Committee on Aboriginal Peoples: Ottawa, ON, Canada, 2007.

79. Slocombe, S. Evidence of the Intervenor, Northwatch; Willms and Shier, Environmental Lawyers LLP: Toronto, ON, Canada, 2008.

80. Ostrom, A.R. Small hydro development in Canadian remote communities. In Proceedings of the Waterpower 1981, International Conference on Hydropower, Washington, DC, USA, 22 June 1981; pp. 1187-1200.

81. Ah-You, K.; Leng, K. Renewable Energy in Canada's Remote Communities; Natural Resources Canada: Ottawa, ON, Canada, 1999. 
82. Parcher, C. Barriers to the Implementation of Renewable Energy Systems in Remote First Nation Communities; Major Paper; University of Ottawa: Ottawa, ON, Canada, 2004.

83. Weis, T. Specific Issues Regarding First Nations and Wind Energy Development in Québec; Pembina Institute: Calgary, AB, Canada, 2006.

84. Weis, T.; Cobb, P. Aboriginal Energy Alternatives; Pembina Institute: Calgary, AB, Canada, 2008.

85. Weis, T.; Ilinca, A.; Pinard, J.P. Stakeholder's perspectives on barriers to remote wind-diesel power plants in Canada. Energy Policy 2008, 36, 1611-1621. [CrossRef]

86. McDonald, N.; Pearce, J. Renewable Energy Policies and Programs in Nunavut: Perspectives from the Federal and Territorial Governments. Arctic 2012, 65, 465-475. [CrossRef]

87. Inglis, L. Barriers to Renewable Energy Development in British Columbia's Remote Communities; Research Project; Simon Fraser University: Vancouver, BC, Canada, 2012.

88. McDonald, N.; Pearce, J. Community Voices: Perspectives on Renewable Energy in Nunavut. Arctic 2013, 66, 94-104. [CrossRef]

89. IISEM. Powering Prosperity. Working to Build on the Potential of Energy Projects E Partnerships; International Indigenous Summit on Energy and Mining, Assembly of First Nation (AFN): Ottawa, ON, Canada, 2011.

90. Peredo, A.M.; Chrisman, J.J. Toward a theory of community-based enterprise. Acad. Manag. Rev. 2006, 31, 309-328. [CrossRef]

91. IEA. Renewable Energy. Policy Considerations for Deploying Renewables; International Energy Agency: Paris, France, 2011.

92. NT Energy. A Vision for the NWT Power System Plan; NT Energy. 2013. Available online: http:/ / www.iti. gov.nt.ca/sites/default/files/nwt_power_systems_plan_december2013.pdf (accessed on 5 February 2015).

93. OME. Achieving Balance: Ontario's Long Term Energy Plan; Ontario Ministry of Energy: Toronto, ON, Canada, 2013.

94. Weis, T. Implementation of Wind Energy Projects in the Autonomous Networks and Their Coupling with Diesel Powered Generators; Régie de l'énergie, R-3864-2013-Expert Report; Hydro-Quebec: Montreal, QC, Canada, 2014.

95. GNWT. Creating a Brighter Future: A Review of Electricity Regulation, Rates and Subsidy Programs in the Northwest Territories; Government of Northwest Territories: Yellowknife, NWT, Canada, 2009.

96. GNWT. A Review of Electricity Regulation, Rates and Subsidy Programs in the Northwest Territories; Government of Northwest Territories: Yellowknife, NWT, Canada, 2008.

97. GNWT. Efficient, Affordable and Equitable: Creating a Brighter Future for the Northwest Territories' Electricity System; Government of Northwest Territories: Yellowknife, NWT, Canada, 2010.

98. Baring-Gould, I.; Dabo, M. Technology, Performance, and Market Report of Wind-Diesel Applications for Remote and Island Communities; National Renewable Energy Laboratory (NREL). 2007. Available online: http:/ / www.nrel.gov/wind/pdfs / 45810.pdf (accessed on 13 March 2015).

99. GY. Budget Highlights; Government of Yukon. 2015. Available online: http://www.finance.gov.yk.ca/pdf/ budget/highlights.pdf (accessed on 19 May 2016).

100. BC Hydro. BC Hydro's Service Plan 2014/15-2016/17; BC Hydro. 2015. Available online: https: / /www.bchydro.com/content/dam/BCHydro/customer-portal/documents/corporate/regulatory-planning -documents/service-plans/bchydro-service-plan-2014-15-2016-17.pdf (accessed on 15 October 2017).

101. Hydro One. 2009 Revenue Requirements and Rates Application-Application and Prefiled Evidence; Hydro One: Toronto, ON, Canada, 2008.

102. Hydro One. 2013 Revenue Requirement and Rates Application-Application and Prefiled Evidence; Hydro One: Toronto, ON, Canada, 2012.

103. Nunavut Energy. Nunavut's Energy System. Available online: http://www.nunavutenergy.ca/Nunavut s_Energy_System (accessed on 5 December 2017).

104. Public Policy Forum. Sharing in the Benefits of Resource Developments: A Study of First Nations-Industry Impact Benefits Agreements; Public Policy Forum: Ottawa, ON, Canada, 2006.

105. IISD. The Tahltan, Mining, and the Seven Questions to Sustainability. Report of the Tahltan Mining Symposium, April 4-6, 2003; IISD and the Tahltan First Nation: Dease Lake, BC, Canada, 2013.

106. Five Nations Energy Inc. 2016. Available online: http://www.fivenations.ca/docs/PR\%205\%20years.pdf (accessed on 14 October 2017). 
107. Atleo, C. From Indigenous Nationhood to Neoliberal Aboriginal Economic Development: Charting the Evolution of Indigenous-Settler Relations in Canada; Canadian Social Economy Hub. 2008. Available online: http:/ / www.socialeconomyhub.ca/?q=content/indigenous (accessed on 31 October 2017).

108. Atleo, S. Resources, Risks and Responsibilities. A First Nations Perspective on Canada's Resource Agenda; The Vancouver Board of Trade. 2013. Available online: http:/ /www.afn.ca/uploads/files/13-09-25_nc_spe aking_notes_vbot_fe.pdf (accessed on 5 February 2018).

109. Coates, K.; Crowley, B.L. New Beginnings: How Canada's Natural Resource Wealth Could Reshape Relations with Aboriginal People; MacDonald-Laurier Institute for Public Policy: Ottawa, ON, Canada, 2013.

110. Booth, A.; Halseth, G. Why the public thinks natural resources public participation processes fail: A case study of British Columbia communities. Land Use Policy 2011, 28, 898-906. [CrossRef]

111. Alcantara, C. Negotiating the Deal-Comprehensive Land Claims Agreements in Canada; University of Toronto Press: Toronto, ON, Canada, 2013.

112. St. Denis, G.; Parker, P. Community energy planning in Canada: The role of renewable energy. Renew. Sustain. Energy Rev. 2009, 13, 2088-2095.

113. Krupa, J. Identifying barriers to aboriginal renewable energy deployment in Canada. Energy Policy 2012, 42, 710-714. [CrossRef]

114. Gingras, Y.; Dalp, R. Energy R\&D policy in Canada. In Science and Technology; Dela Mothe, J., Dufour, B., Eds.; Longman: London, UK, 1993; pp. 162-180.

115. Wesley-Esquimaux, C.; Calliou, B. Best Practices in Aboriginal Community Development: A Literature Review and Wise Practices Approach; The Banff Centre: Banff, AB, Canada, 2010.

116. GNWT. Energy Priorities Framework; Government of Northwest Territories: Yellowknife, NWT, Canada, 2008.

117. GNWT. Northwest Territories Energy Report; Government of Northwest Territories: Yellowknife, NWT, Canada, 2011.

118. AEA. Communities. Available online: http:/ /aea.nt.ca/communities (accessed on 3 March 2016).

119. ARI. Wind and Solar Energy Potential. Available online: http://nwtresearch.com/projects/energy/windand-solar-energy-potential (accessed on 5 January 2016).

120. Campbell, B.; Pape, A. Economic Development from Renewable Energy; Pembina Institute. 1999. Available online: http:/ / www.pembina.org/reports/yukon.pdf (accessed on 28 December 2014).

121. CBC. Lutsel K'e Dene First Nation Enters the Power Business. Available online: http://www.cbc.ca/news/c anada/north/lutsel-ke-power-business-1.3602415 (accessed on 30 November 2017).

122. AANDC. ecoENERGY for Aboriginal and Northern Communities Program. Presentation at Northern Ontario First Nations Environment Conference. 2014. Available online: http:/ / www.nofnec.ca/PDF/Presentations/eco ENERGY-Program.pdf (accessed on 15 January 2015).

123. INAC. Empowering People. Canada's Aboriginal and Northern Communities Action Program (ANCAP); Indigenous and Northern Affairs Canada: Ottawa, ON, Canada, 2005.

124. GNWT. Energy for the Future. An Energy Plan for the Northwest Territories; Government of Northwest Territories: Yellowknife, NWT, Canada, 2007.

125. GNWT. A Greenhouse Gas Strategy for the Northwest Territories 2011-2015; Government of Northwest Territories: Yellowknife, NWT, Canada, 2011.

126. NTPC. Remote Community Wind Energy Conference, Tuktoyaktuk, NT. Available online: http:/ / www.enr. gov.nt.ca/files/remote-community-wind-energy-conference (accessed on 15 April 2016).

127. AANDC. ecoENERGY for Aboriginal and Northern Communities Program (EANCP) 2011-2016. Available online: http:/ / www.aadnc-aandc.gc.ca/eng/1100100034258/1100100034259\#ch3c (accessed on 12 July 2014).

128. Carpenter, W. Solar Energy in the Northwest Territories. Renewables in Remote Microgrids Conference. Toronto. 2013. Available online: https://wise.uwaterloo.ca/documents/events/public/renewable_in_r emote_microgrids_conference/solarenergyinthenorthwestterritorieswadecarpentergovernmentofnwtpdf (accessed on 15 October 2017).

129. GNWT. Electricity Review: A Discussion with Northerners about Electricity; Government of Northwest Territories: Yellowknife, NWT, Canada, 2009.

130. Bhattacharyya, S. Review of alternative methodologies for analysing off-grid electricity supply. Renew. Sustain. Energy Rev. 2012, 16, 677-694. [CrossRef]

131. NFL Hydro. Preliminary Assessment of Alternative Energy Potential in Coastal Labrador; NFL Hydro. 2009. Available online: http:/ / www.nr.gov.nl.ca/nr/publications/energy/preliminary_assessment_of_alternat ive_energy_potential_in_coastal_labrador.pdf (accessed on 22 October 2015). 
132. Bhattarai, P.; Thompson, S. Optimizing an Off-Grid Electrical System in Brochet, Manitoba, Canada. Renew. Sustain. Energy Rev. 2016, 53, 709-719. [CrossRef]

133. GNWT. Northwest Territories Solar Energy Strategy 2012-2017; Government of Northwest Territories: Yellowknife, NWT, Canada, 2012.

134. GNWT. 2012 Northwest Territories Energy Charrette; Government of Northwest Territories: Yellowknife, NWT, Canada, 2012.

135. GNWT. Northwest Territories Energy Action Plan; Government of Northwest Territories: Yellowknife, NWT, Canada, 2013. Available online: http://www.mrif.gouv.qc.ca/PDF/actualites/nwt_energy_acti on_plan_december2013.pdf (accessed on 5 February 2015).

136. RMA. 2014 NWT Energy Charette Final Report; R. Marshall \& Associates: Yellowknife, NWT, Canada, 2014.

137. GNWT. GNWT Response to the 2014 NWT Energy; Government of Northwest Territories: Yellowknife, NWT, Canada, 2015.

138. GNWT. "Net Metering". Northwest Territories Power Corporation. Available online: https://www.ntpc.com/c ustomer-service/net-billing (accessed on 22 December 2017).

139. Cherniak, D.; Dufresne, V.; Keyte, L.; Mallett, A.; Scott, S. Report on the State of Alternative Energy in the Arctic; School of Public Policy and Administration, Carleton University: Ottawa, ON, Canada, 2015.

140. NAN-HORCI. Nishnawbe Aski Nation (NAN) Interrogatories-HORCI. 2013 Rates Rebasing Application-EB-2012-0137; NAN and Hydro One Remote Communities Inc.: Thunder Bay, ON, Canada, 2013.

141. NAN. 2012 NAN Chiefs Energy Conference Presentations-Energy Overview in Nishnawbe Aski Nation Territory. Available online: http:/ / www.nan.on.ca/upload/documents/energy2012-pr-ed-hoshizaki---co mmunity-energy-needs.pdf (accessed on 23 January 2014).

142. UW. Bringing Green Energy to Remote Canadian Communities. Available online: https://uwaterloo.ca/st ories/bringing-green-energy-remote-canadian-communities (accessed on 15 July 2016).

143. Ontario Ministry of Energy. Canadian Solar. Available online: http://www.energy.gov.on.ca/en/smart-gr id-fund/smart-grid-fund-projects / canadian-solar/ (accessed on 6 April 2016).

144. STS. Shibogama Technical Services (STS). Available online: http://www.shibogama.on.ca/?q=technicalservices (accessed on 15 March 2016).

145. NCC. In the News. Available online: http:/ / www.nccsolar.com/media/news/wynne-government-announcement/ (accessed on 15 March 2016).

146. Schot, J.; Geels, F. Strategic niche management and sustainable innovation journeys: Theory, findings, research agenda, and policy. Technol. Anal. Strateg. Manag. 2008, 20, 537-554. [CrossRef]

147. Smith, A.; Raven, R. What is protective space? Reconsidering niches in transitions to sustainability. Res. Policy 2012, 41, 1025-1036. [CrossRef]

148. Rowlands, I. The Development of Renewable Electricity Policy in the Province of Ontario: The Influence of Ideas and Timing. Rev. Policy Res. 2007, 24, 185-207. [CrossRef]

149. Stokes, L. The politics of renewable energy policies: The case of feed-in tariffs in Ontario, Canada. Energy Policy 2013, 56, 490-500. [CrossRef]

150. Winfield, M. Understanding the Economic Impact of Renewable Energy Initiatives: Assessing Ontario's Experience in a Comparative Context; Sustainable Energy Initiative, Faculty of Environmental Studies, York University: Toronto, ON, Canada, 2013.

151. OFA. Aboriginal Loan Guarantee Program. Available online: https://www.ofina.on.ca/algp/ (accessed on 5 December 2016).

152. AEPP. About the Aboriginal Energy Partnerships Program. Available online: http:/ / www.aboriginalenergy. ca/about-aboriginal-energy-partnerships-program (accessed on 14 June 2016).

153. HORCI. 2011 Greenhouse Gas Inventory Report and Action Plan; Hydro One Remote Communities Inc.: Thunder Bay, ON, Canada, 2012.

154. HORCI. Hydro One Remote Communities Inc. Renewable Energy INnovation DiEsel Emission Reduction (REINDEER) Guideline; Hydro One Remote Communities Inc.: Thunder Bay, ON, Canada, 2015.

155. IESO. Draft Technical Report and Business Case for the Connection of Remote First Nation Communities in Northwest Ontario. Available online: http:/ / www.ieso.ca/-/media/files/ieso/document-library/regional-planni ng/remote-community-connection/opa-technical-report-2014-08-21.pdf?la=en (accessed on 31 October 2017). 
156. PWC. Wataynikaneyap Power Project-Socioeconomic Impact Analysis of Building Grid Connection to Ontario's Remote Communities. Available online: http:/ / www.wataypower.ca/sites/default/files/Wataynikaneyap\%20P ower\%20Project\%20-\%20PWC\%20Socioeconomic\%20Impact\%20Analysis\%20-\%20June\%2017\%202015.pdf (accessed on 5 October 2017).

157. WP. Project Benefits Study: Social, Environmental and Economic Analysis: Wataynikaneyap Power Project. Wataynikaneyap Power-Lumos Energy. Available online: http:/ / www.wataypower.ca/sites/default/files/Proj ect \%20Benefits\%20Study\%20-\%20Wataynikaneyap\%20Power.pdf (accessed on 2 June 2016).

158. WP. Home. Available online: http:/ / www.wataypower.ca/ (accessed on 24 June 2017).

159. CBC. Colville Lake, NWT, Now Powered by Solar/Diesel Hybrid System. Available online: http:/ /www.cbc.ca/ news/canada/north/colville-lake-solar-diesel-hybrid-power-1.3441205 (accessed on 15 December 2017).

160. CBC. An Off-Grid Community Goes Solar, and Gets Closer to Its Roots. Available online: http:/ /www.cbc.c a/news/canada/north/colville-lake-solar-power-1.3604310 (accessed on 30 November 2017).

161. CBC. CBC News North. Available online: http://www.cbc.ca/news/canada/north/arctic-renewable-energ y-collaboration-1.3769585 (accessed on 30 November 2017).

162. GNWT. Energy Strategy Discussion Guide; Government of Northwest Territories: Yellowknife, NWT, Canada, 2016.

163. GNWT. 2030 Energy Strategy-A Path to More Affordable, Secure and Sustainable Energy in the Northwest Territories; Government of Northwest Territories: Yellowknife, NWT, Canada, 2017.

164. Bullfrog Power. Renewables in Remote Microgrids Conference-Yellowknife. Available online: http://gogreen.bu llfrogpower.com/microgrids2015-home (accessed on 9 September 2016).

165. Geels, F.; Raven, R. Non-linearity and Expectations in Niche-Development Trajectories: Ups and Downs in Dutch Biogas Development (1973-2003). Technol. Anal. Strateg. Manag. 2006, 18, 375-392. [CrossRef]

166. OME. Ontario's Long Term Energy Plan-Delivering Fairness and Choice; Ontario Ministry of Energy: Toronto, ON, Canada, 2017.

167. CBC. Yukon, N.W.T. and Nunavut Differ in Outlooks for Renewable Energy. Available online: http:/ / www.cbc.c a/news / canada/north/yukon-n-w-t-and-nunavut-differ-in-outlooks-for-renewable-energy-1.2804345 (accessed on 5 October 2016).

168. INAC. Evaluation of the ecoENERGY for Aboriginal and Northern Communities Program. Available online: https: / www.aadnc-aandc.gc.ca/eng/1465235699114/1465236134726 (accessed on 12 December 2017).

169. Musiolik, J.; Markard, J. Creating and shaping innovation systems: Formal networks in the innovation system for stationary fuel cells in Germany. Energy Policy 2011, 39, 1909-1922. [CrossRef]

170. Fischer, L.B.; Newig, J. Importance of actors and agency in sustainability transitions: A systematic exploration of the literature. Sustainability 2016, 8, 476. [CrossRef]

171. GN. Ikummatiit: The Government of Nunavut Energy Strategy; Government of Nunavut: Iqaluit, NU, Canada, 2007.

172. Maissan, J. A Report on the State-Of-The-Art and Economic Viability of Wind Power Development in Arctic Communities; Aurora Research Institute, Aurora College: Inuvik, NWT, Canada, 2006.

173. Maissan, J. Report on Wind Energy for Small Communities; Leading Edge Projects Inc. 2006. Available online: http:/ / www.energy.gov.yk.ca/pdf/wind_energy_for_small_communities_april_2006.pdf (accessed on 22 October 2015).

174. Nunavut Power. Wind Power Generation; Regie de l'energie doss. R-3526-2004; Hydro-Quebec: Montreal, QC, Canada, 2004.

175. Rohner, T. Peterson Pulls the Plug on Nunavut MLA's Green Energy Dreams. Available online: http:/ / www.nunat siaqonline.ca/stories/article/65674peterson_pulls_the_plug_on_nunavut_mlas_green_energy_dreams/ (accessed on 15 June 2016).

176. Krohn, S. Wind-Diesel Systems in Nunavik and Other Autonomous Grids; Regroupement National des Conseils Régionaux de L'environnement du Québec (RNCREQ): Montreal, QC, Canada, 2005.

177. GQ. Partnership Agreement on Economic and Community Development in Nunavik (Sanarrutik Agreement). Government of Quebec. Available online: http://www.saa.gouv.qc.ca/relations_autochtones/ententes/inuit s/sanarrutik-consolidee_en.pdf (accessed on 6 June 2016).

178. NO. Nunavik Wants to Join Quebec Power Grid: Plan Nunavik. Available online: http:/ /www.nunatsiaqonline.c a/stories/article/20889_nunavik_wants_to_join_quebecs_power_grid (accessed on 14 June 2016).

179. Rogers, S. Hydro-Québec Says Nunavik Wind, Underwater Power Projects "Not Profitable". Available online: http:/ /www.nunatsiaqonline.ca/stories/article/65674hydro_quebec_says_wind_underwater_power_p rojects_not_profitable/ (accessed on 15 June 2016). 
180. Hegger, D.; VanVliet, J.; VanVliet, B. Niche Management and its Contribution to Regime Change: The Case of Innovation in Sanitation. Technol. Anal. Strateg. Manag. 2007, 19, 729-746. [CrossRef]

181. AANDC. Climate Change Adaptation Program. Available online: http://www.aadnc-aandc.gc.ca/eng/ 1100100034585/1100100034586 (accessed on 10 August 2018).

182. ARI. Pre-Feasibility Analysis of Wind Energy for Inuvialuit Region in Northwest Territories; Aurora Research Institute: Inuvik, NWT, Canada, 2003.

183. Pinard, J. Executive Progress Report for Wind Energy Monitoring in Six Communities in the NWT; Aurora Research Institute: Inuvik, NWT, Canada, 2007.

184. Pinard, J.; Maissan, J. Colville Lake Wind Pre-Feasibility Analysis; Aurora Research Institute: Inuvik, NWT, Canada, 2008.

185. AEA. Guide to Best Energy Practices for Remote Facilities; Arctic Energy Alliance: Yellowknife, NWT, Canada, 2011.

186. GNWT. 2014 Northwest Territories Energy Charrette; Government of Northwest Territories: Yellowknife, NWT, Canada, 2014.

187. NAN. NAN Chiefs Energy Conference Report. Nishnawbe Aski Nation. Available online: http:/ /www.nan.o n.ca/upload/documents/pub---2012-energy-conference-report-jdb.pdf (accessed on 7 November 2016).

188. IESO. Aboriginal Renewable Energy Network. Available online: http:/ / www.aboriginalenergy.ca/ (accessed on 12 December 2016).

189. Wawatay News. Deer Lake Celebrates Ground-Breaking Solar Power System. Available online: http://ww w.wawataynews.ca/wwt/home/deer-lake-celebrates-ground-breaking-solar-power-system (accessed on 15 June 2016).

(C) 2018 by the authors. Licensee MDPI, Basel, Switzerland. This article is an open access article distributed under the terms and conditions of the Creative Commons Attribution (CC BY) license (http:/ / creativecommons.org/licenses/by/4.0/). 